USGS Climate and Land Use Change Research and Development Program

\title{
Well Network Installation and Hydrogeologic Data Collection, Assateague Island National Seashore, Worcester County, Maryland, 2010
}

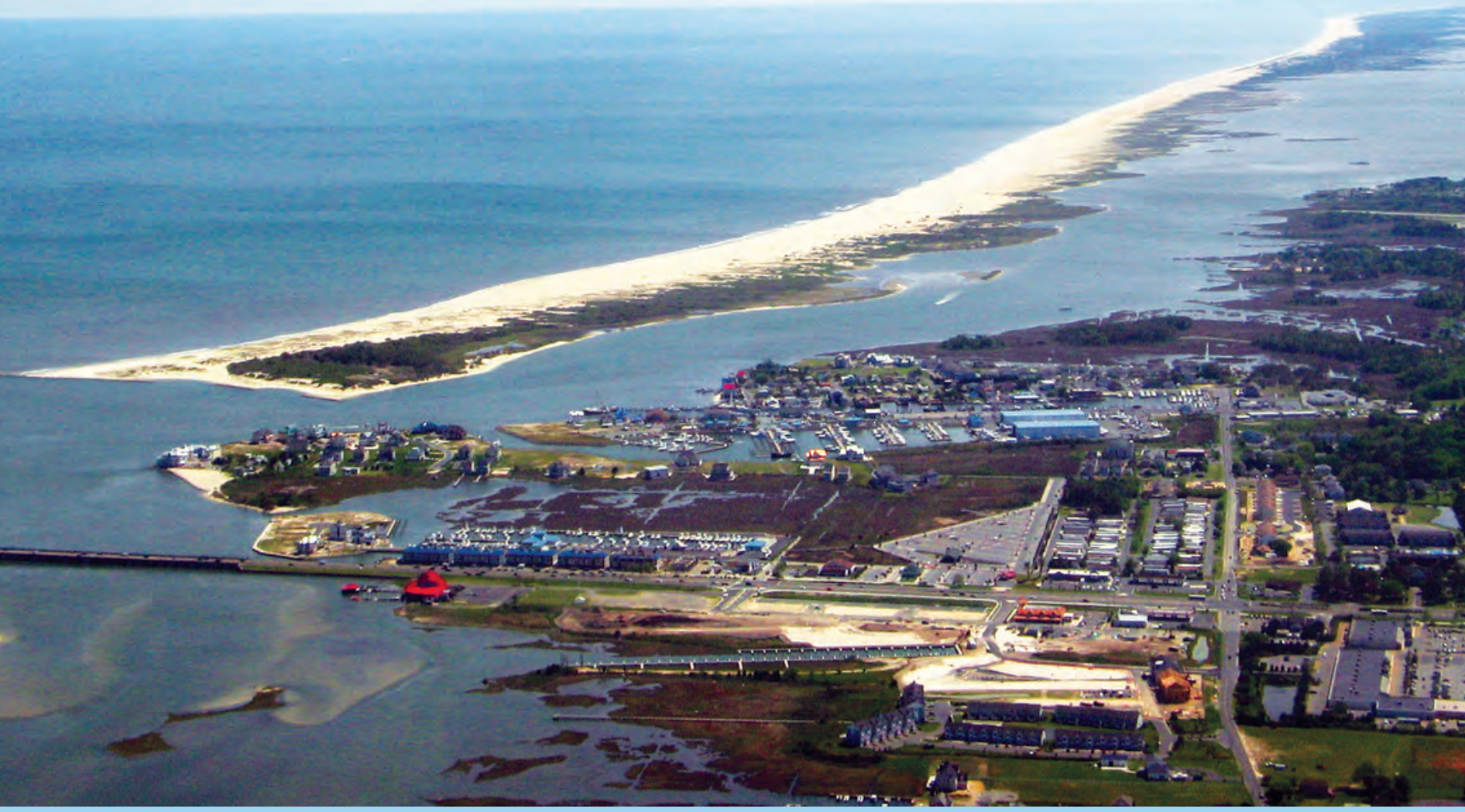

Scientific Investigations Report 2012-5079 


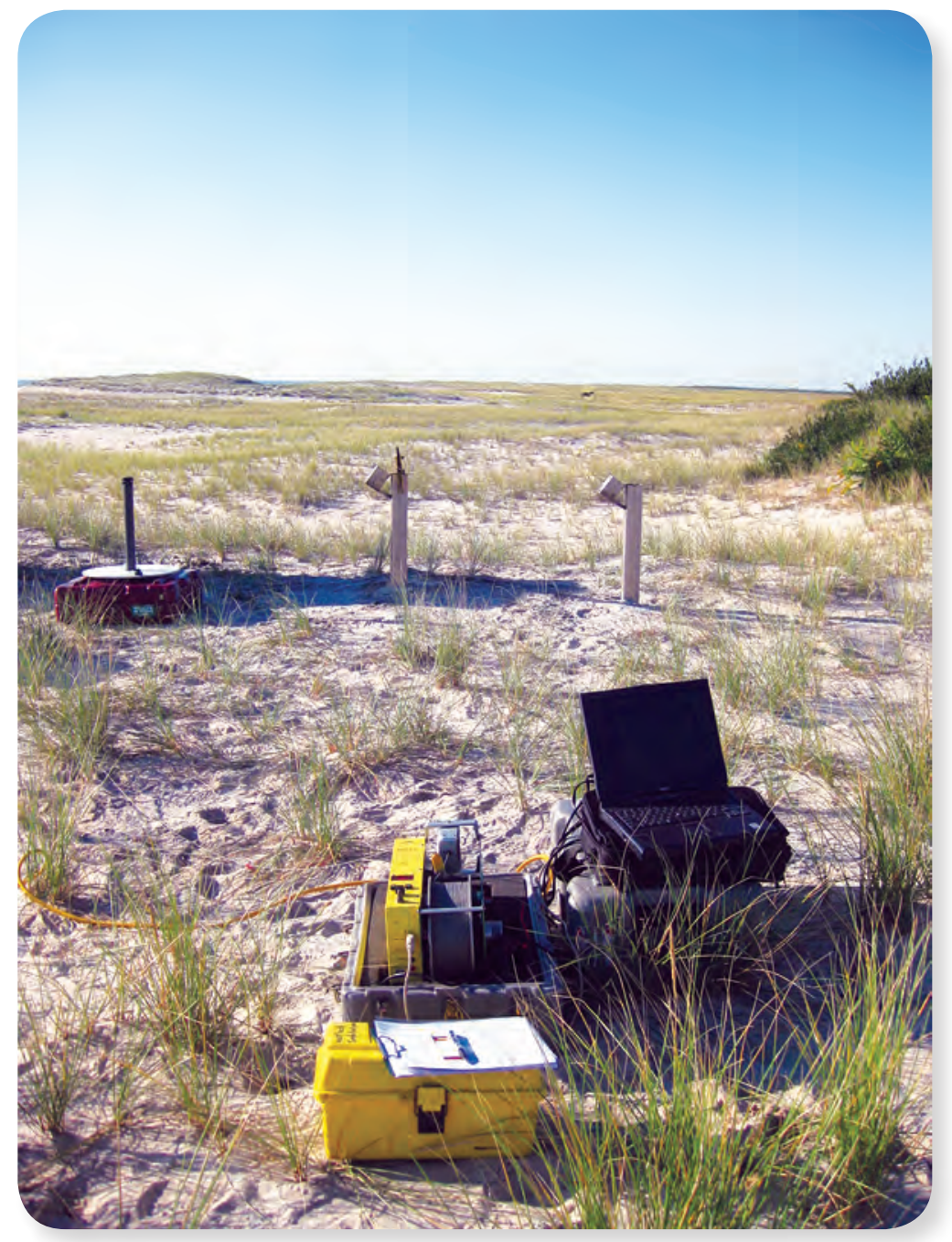

Borehole geophysical logging in observation wells near Kilometer Marker 3 (KM3), Assateague Island National Seashore, Worcester County, Maryland. [Photograph by John Masterson, U.S. Geological Survey.]

Cover. View looking south at West Ocean City, Maryland, Assateague Island, and Sinepuxent Bay. Photograph by Joanna Woerner, IAN Image Library (www.ian.umces.edu/imagelibrary/). 


\section{Well Network Installation and Hydrogeologic Data Collection, Assateague Island National Seashore, Worcester County, Maryland, 2010}

By William S.L. Banks, John P. Masterson, and Carole D. Johnson

USGS Climate and Land Use Change Research and Development Program

Scientific Investigations Report 2012-5079 


\section{U.S. Department of the Interior \\ KEN SALAZAR, Secretary \\ U.S. Geological Survey \\ Marcia K. McNutt, Director}

U.S. Geological Survey, Reston, Virginia: 2012

For more information on the USGS - the Federal source for science about the Earth, its natural and living resources, natural hazards, and the environment, visit http://www.usgs.gov or call 1-888-ASK-USGS

For an overview of USGS information products, including maps, imagery, and publications, visit http://www.usgs.gov/pubprod

To order this and other USGS information products, visit http://store.usgs.gov

Any use of trade, product, or firm names is for descriptive purposes only and does not imply endorsement by the U.S. Government.

Although this report is in the public domain, permission must be secured from the individual copyright owners to reproduce any copyrighted materials contained within this report.

Suggested citation:

Banks, W.S.L., Masterson, J.P., and Johnson, C.D., 2012, Well network installation and hydrogeologic data collection, Assateague Island National Seashore, Worcester County, Maryland, 2010: U.S. Geological Survey Scientific Investigations Report 2012-5079, 20 p. 


\section{Contents}

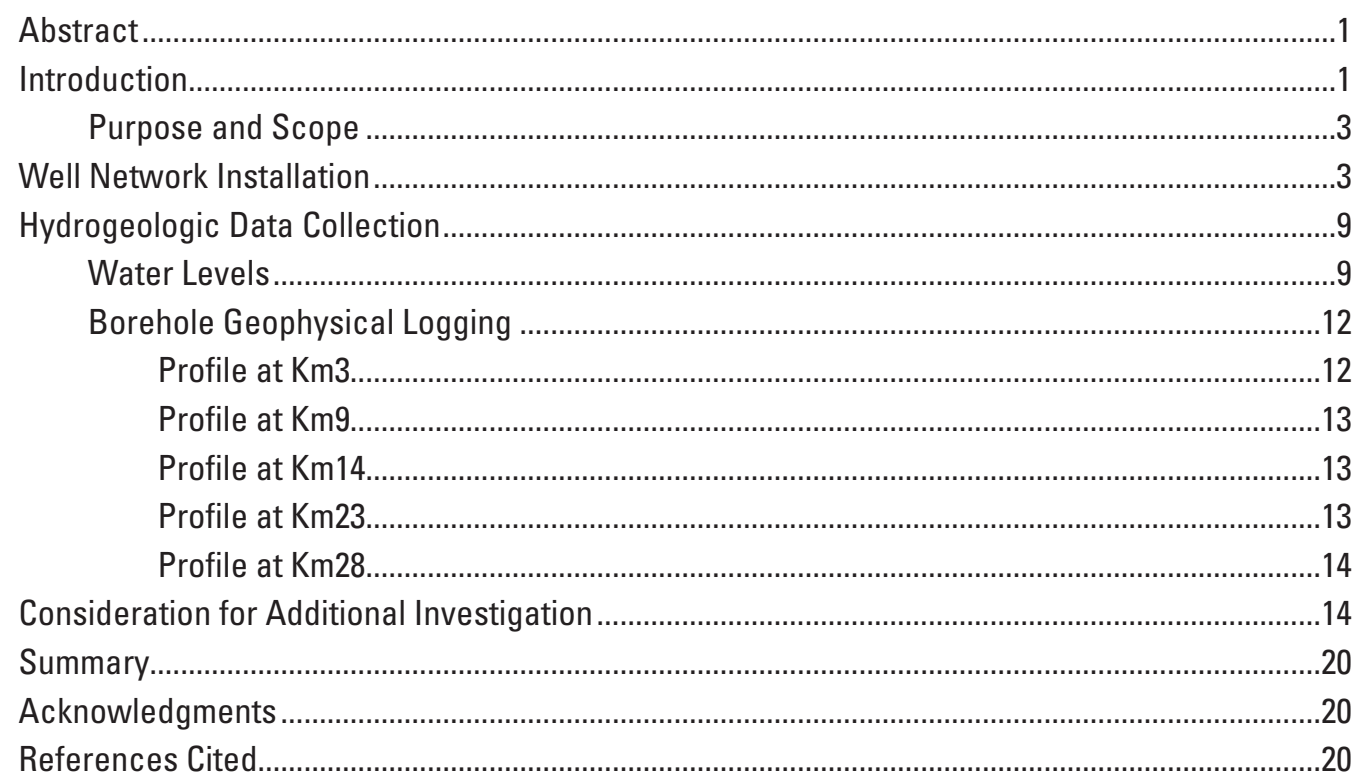




\section{Figures}

1-2. Maps showing-

1. Location of Assateague Island National Seashore study area, Worcester County, Maryland.

2. Well locations on Assateague Island National Seashore, Worcester County, Maryland.

3. Photograph showing truck-mounted hollow-stem auger drill rig used for monitoring well installation on Assateague Island National Seashore,

Worcester County, Maryland.

4-5. Graphs showing-

4. Continuous water-level data, intermittent manual measurements, tide altitude data, and total daily precipitation data for the shallow monitoring wells at $\mathrm{Km} 9 \mathrm{~A}$, Km23A, Km23D, and $\mathrm{Km} 28 \mathrm{~A}$ from August 12 to September 28, 2010, Assateague Island National Seashore, Maryland

5. Continuous water-level data, intermittent manual measurements, tide altitude data, and total daily precipitation data for the deeper monitoring wells at Km9A, Km23A, Km23D, Km28A, and Km28B from August 12 to September 28, 2010, Assateague Island National Seashore, Maryland

6a-6e. Diagrams showing-

6a. Natural gamma and electromagnetic induction logs collected at transect Km3, Assateague Island National Seashore, Maryland ...

6b. Natural gamma and electromagnetic induction logs collected at transect Km9, Assateague Island National Seashore, Maryland

6c. Natural gamma and electromagnetic induction logs collected at transect Km14, Assateague Island National Seashore, Maryland

6d. Natural gamma and electromagnetic induction logs collected at transect Km23, Assateague Island National Seashore, Maryland

6e. Natural gamma and electromagnetic induction logs collected at transect Km28, Assateague Island National Seashore, Maryland

\section{Table}

1. Location, physical characteristics, and water-level information for 26 wells, Assateague Island National Seashore, Maryland, 2010 


\section{Conversion Factors and Datums}

\begin{tabular}{|c|c|c|}
\hline Multiply & By & To obtain \\
\hline \multicolumn{3}{|c|}{ Length } \\
\hline inch (in.) & 2.54 & centimeter $(\mathrm{cm})$ \\
\hline mile (mi) & 1.609 & kilometer (km) \\
\hline \multicolumn{3}{|c|}{ Area } \\
\hline acre & $4,047.0$ & square meter $\left(\mathrm{m}^{2}\right)$ \\
\hline square mile $\left(\mathrm{mi}^{2}\right)$ & 2.590 & square kilometer $\left(\mathrm{km}^{2}\right)$ \\
\hline \multicolumn{3}{|c|}{ Volume } \\
\hline gallon (gal) & 3.785 & liter $(\mathrm{L})$ \\
\hline \multicolumn{3}{|c|}{ Flow rate } \\
\hline inch per year (in/yr) & 2.54 & centimeter per year $(\mathrm{cm} / \mathrm{yr})$ \\
\hline gallon per day (gal/d) & 3.785 & liter per day $(\mathrm{L} / \mathrm{d})$ \\
\hline \multicolumn{3}{|c|}{ Pressure } \\
\hline pound per square inch $\left(\mathrm{lb} / \mathrm{in}^{2}\right)$ & 6.895 & kilopascal (kPa) \\
\hline \multicolumn{3}{|c|}{ Density } \\
\hline pound per cubic foot $\left(\mathrm{lb} / \mathrm{ft}^{3}\right)$ & 0.01602 & gram per cubic centimeter $\left(\mathrm{g} / \mathrm{cm}^{3}\right)$ \\
\hline
\end{tabular}

Temperature in degrees Fahrenheit $\left({ }^{\circ} \mathrm{F}\right)$ may be converted to degrees Celsius $\left({ }^{\circ} \mathrm{C}\right)$ as follows:

$$
{ }^{\circ} \mathrm{C}=\left({ }^{\circ} \mathrm{F}-32\right) / 1.8
$$

Specific conductance is given in microsiemens per centimeter at 25 degrees Celsius $(\mu \mathrm{S} / \mathrm{cm}$ at $\left.25^{\circ} \mathrm{C}\right)$.

Vertical coordinate information is referenced to the North American Vertical Datum of 1988 (NAVD 88).

Horizontal coordinate information is referenced to the North American Datum of 1983 (NAD 83).

Altitude, as used in this report, refers to distance above the vertical datum. 



\title{
Well Network Installation and Hydrogeologic Data Collection, Assateague Island National Seashore, Worcester County, Maryland, 2010
}

\author{
By William S.L. Banks, John P. Masterson, and Carole D. Johnson
}

\section{Abstract}

The U.S. Geological Survey, as part of its Climate and Land Use Change Research and Development Program, is conducting a multi-year investigation to assess potential impacts on the natural resources of Assateague Island National Seashore, Maryland that may result from changes in the hydrologic system in response to projected sea-level rise. As part of this effort, 26 monitoring wells were installed in pairs along five east-west trending transects. Each of the five transects has between two and four pairs of wells, consisting of a shallow well and a deeper well. The shallow well typically was installed several feet below the water table - usually in freshwater about 10 feet below land surface (ft bls) - to measure water-level changes in the shallow groundwater system. The deeper well was installed below the anticipated depth to the freshwater-saltwater interface - usually in saltwater about 45 to $55 \mathrm{ft}$ bls - for the purpose of borehole geophysical logging to characterize local differences in lithology and salinity and to monitor tidal influences on groundwater.

Four of the 13 shallow wells and 5 of the 13 deeper wells were instrumented with water-level recorders that collected water-level data at 15 -minute intervals from August 12 through September 28, 2010. Data collected from these instrumented wells were compared with tide data collected north of Assateague Island at the Ocean City Inlet tide gage, and precipitation data collected by National Park Service staff on Assateague Island. These data indicate that precipitation events coupled with changes in ambient sea level had the largest effect on groundwater levels in all monitoring wells near the Atlantic Ocean and Chincoteague and Sinepuxent Bays, whereas precipitation events alone had the greatest impact on shallow groundwater levels near the center of the island. Daily and bi-monthly tidal cycles appeared to have minimal influence on groundwater levels throughout the island and the water-level changes that were observed appeared to vary among well sites, indicating that changes in lithology and salinity also may affect the response of water levels in the shallow and deeper groundwater systems throughout the island.

Borehole geophysical logs were collected at each of the 13 deeper wells along the 5 transects. Electromagnetic induction logs were collected to identify changes in lithology; determine the approximate location of the freshwater-saltwater interface; and characterize the distribution of fresh and brackish water in the shallow aquifer, and the geometry of the fresh groundwater lens beneath the island. Natural gamma logs were collected to provide information on the geologic framework of the island including the presence and thickness of finergrained deposits found in the subsurface throughout the island during previous investigations.

Results of this investigation show the need for collection of continuous water-level data in both the shallow and deeper parts of the flow system and electromagnetic induction and natural gamma geophysical logging data to better understand the response of this groundwater system to changes in precipitation and tidal forcing. Hydrologic data collected as part of this investigation will serve as the foundation for the development of numerical flow models to assess the potential effects of climate change on the coastal groundwater system of Assateague Island.

\section{Introduction}

Assateague Island lies along the Atlantic coast of Maryland and Virginia (fig. 1). It is an undeveloped barrier island complex backed by wetland and marsh systems and consists of large stretches of dunes separated by low-lying areas that often are submerged or overwashed during storm surges. This barrier island complex is characterized by low topographic relief with a mean altitude of about 6.6 feet (ft) 


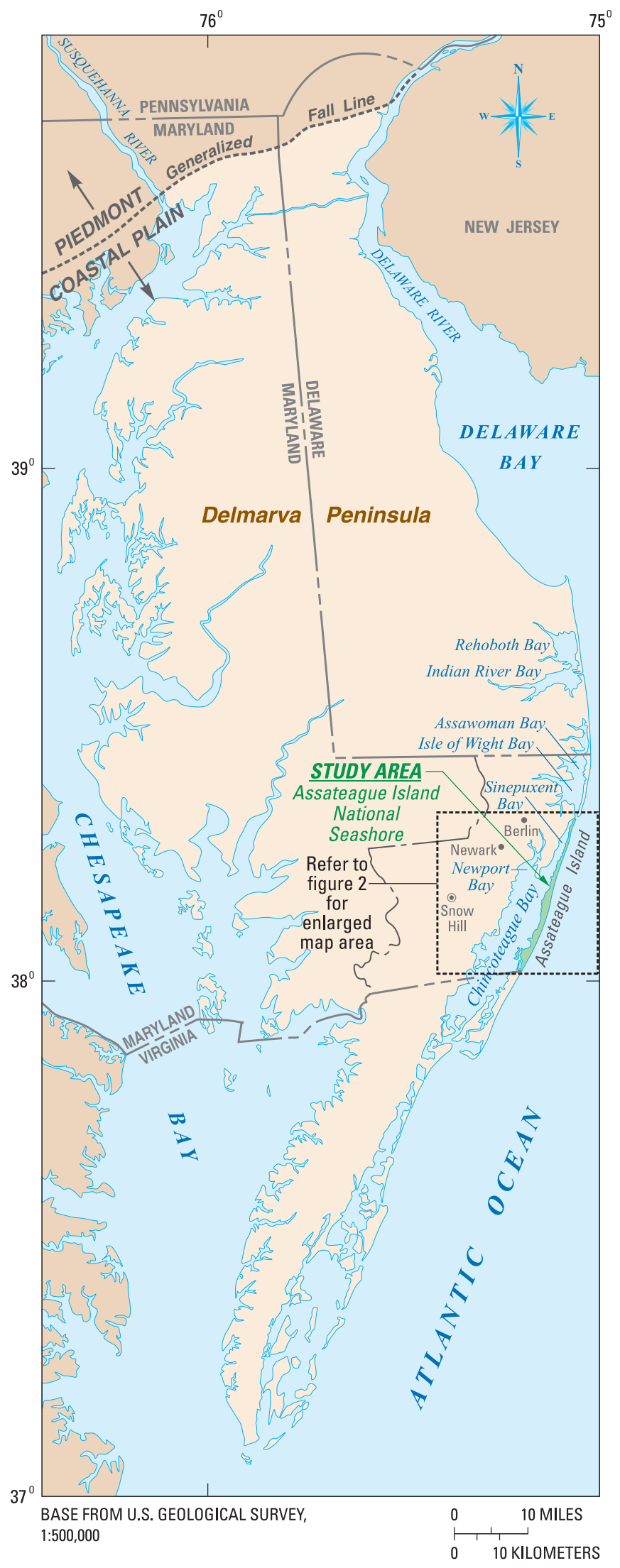

Figure 1. Location of Assateague Island National Seashore study area, Worcester County, Maryland. and maximum dune altitudes of about $33 \mathrm{ft}$ above sea level. The impact of climate change and sea-level rise on this barrier island complex is expected to include changes in erosion rates, island morphology, marsh health, and groundwater flow. These changes will affect use of the island by both humans and wildlife; specifically, the island serves as an important breeding ground and habitat for endangered species such as Piping Plovers. In response to these concerns, the U.S. Geological Survey (USGS) is working with State and other Federal agencies to improve the understanding of climate change on coastal ecosystems, including the effects on groundwater flow, to better develop capabilities for predicting potential climate-change effects and to provide the necessary tools for adaptation and mitigation of potentially adverse impacts.

The study area is underlain by unconsolidated sediments in the Atlantic Coastal Plain that form a wedge of sands, silts, and clays over 7,000 ft thick. These sediments compose a series of confined and unconfined aquifers with flow paths ranging from tens of feet to hundreds of miles collectively known as the Atlantic Coastal Plain (Owens and Denny, 1979). The groundwater hydrology of Assateague Island is controlled largely by the landforms of the island (Krantz, 2009). The confined aquifer system in the study area is generally overlain by younger sediments ranging in age from Tertiary to Quaternary. These sediments were deposited in a variety of environments including alluvial, tidal marsh, back barrier, and marine marginal, and form an unconfined, surficial aquifer.

The water table in the shallow, unconfined aquifer system generally follows the local topography and water levels can range from land surface to as deep as $10 \mathrm{ft}$ below land surface ( $\mathrm{ft} \mathrm{bls);} \mathrm{however,} \mathrm{the} \mathrm{water} \mathrm{table} \mathrm{often} \mathrm{is} \mathrm{less} \mathrm{than} 3 \mathrm{ft}$ bls (Dillow and others, 2002). The only surface-water features on the island are a limited number of groundwater-fed ponds, which represent surface-water expressions of the water table. As a result, the groundwater hydrology, including the distribution of fresh and brackish water in the shallow aquifer, and the geometry of the fresh groundwater lens beneath the island, affects the distribution of plant communities and habitat for a diverse community of invertebrate and vertebrate wildlife (Krantz, 2009).

The areas within Assateague Island that are considered to be most vulnerable to sea-level rise are those with the highest occurrence of overwash and the highest rates of shoreline change (Pendleton and others, 2004). However, in addition to increased erosion and surface inundation from rising sea level, the groundwater flow system can be significantly affected by increased water-table altitude, subsurface flooding of low-lying areas, and the potential for saltwater intrusion (Masterson and Garabedian, 2007). Understanding how sea-level rise may affect groundwater hydrology in shallow, unconfined coastal systems such as Assateague Island may be vital in assessing the potential impacts of sea-level rise on the sustainability of Federally listed endangered species such as Piping Plovers. This information is not currently available to resource managers and decision makers at Assateague Island National Seashore (ASIS). 


\section{Purpose and Scope}

This report describes the study design, drilling methods, and data-collection techniques used to install and monitor a network of 26 groundwater wells for the purpose of assessing the potential impacts of sea-level rise on the natural resources of ASIS (fig. 2). The report also provides a description of the continuous water-level data collected at nine monitoring wells from early August through September 2010 and geophysical logs collected from 13 deeper monitoring wells in October 2010 .

\section{Well Network Installation}

A network of 13 monitoring well pairs was installed to monitor groundwater levels and determine the current depth of the interface between freshwater and saltwater in the shallow groundwater system that underlies ASIS (fig. 2). All of the drilling was completed by the USGS Eastern Region's National Earth Surface Processes Geologic Mapping drilling team from August 1 through August 13, 2010. Well construction information and selected water-level data are provided in table 1. Latitude and longitude data for each well pair were

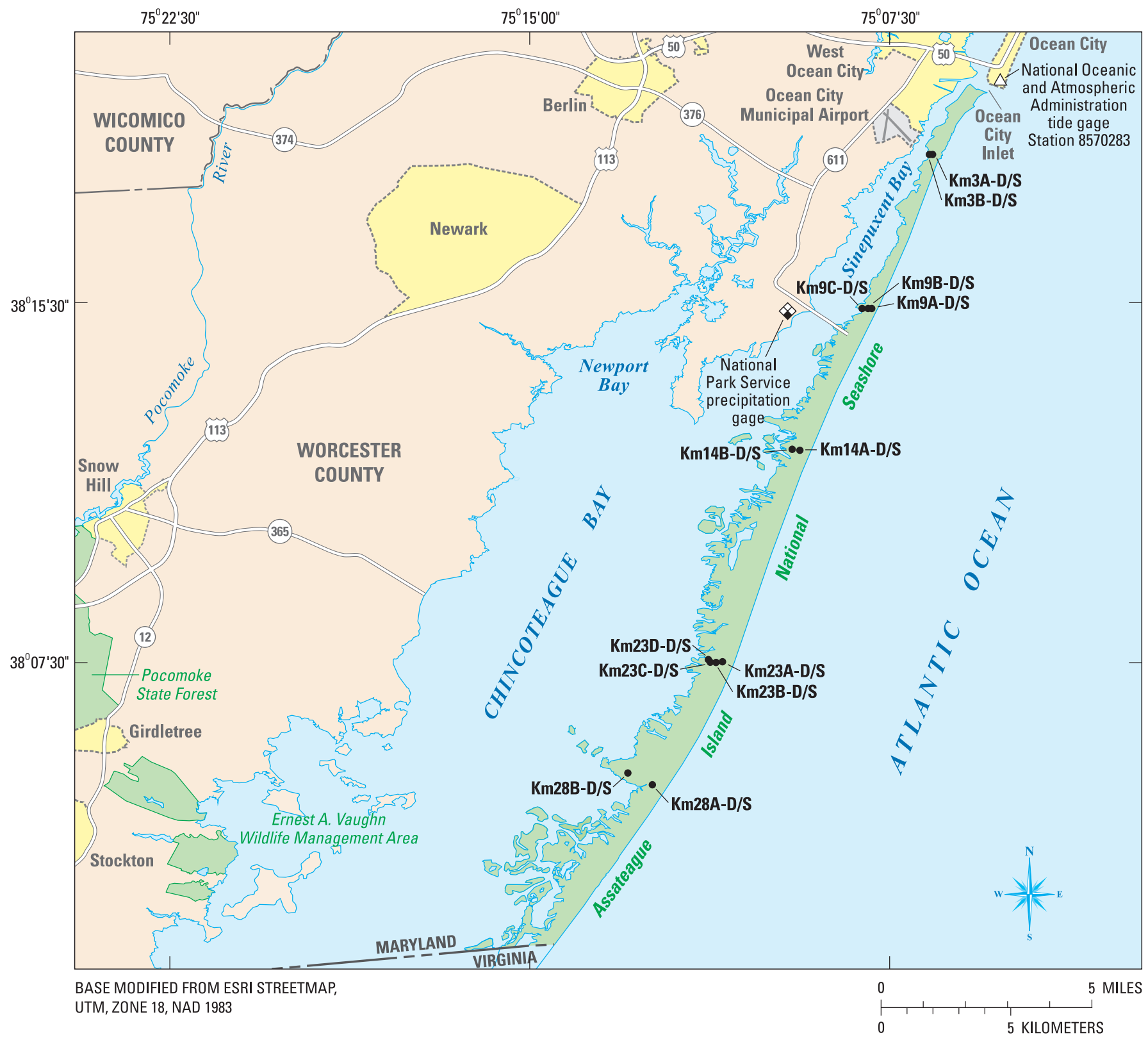

Figure 2. Well locations on Assateague Island National Seashore, Worcester County, Maryland. 


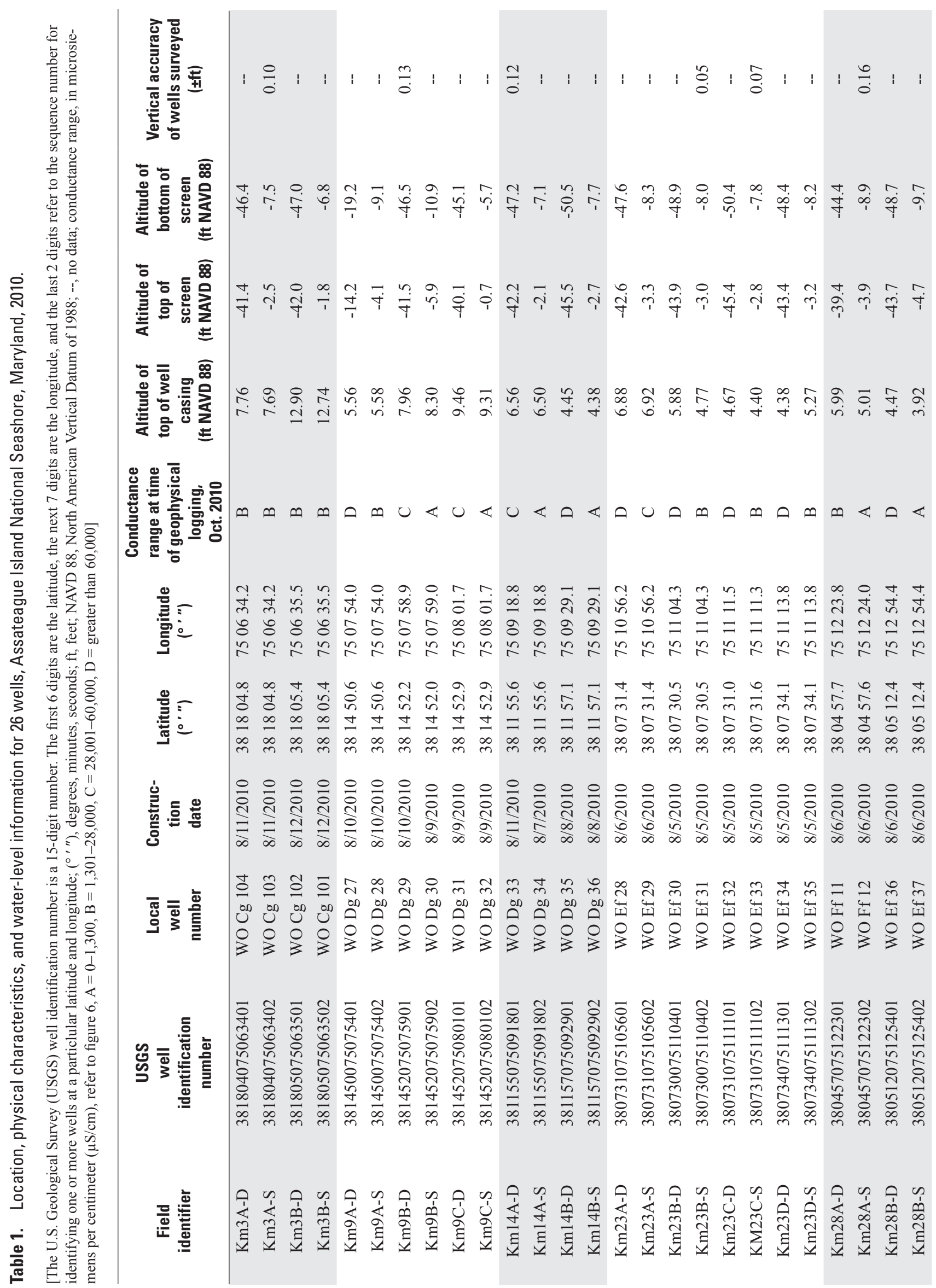




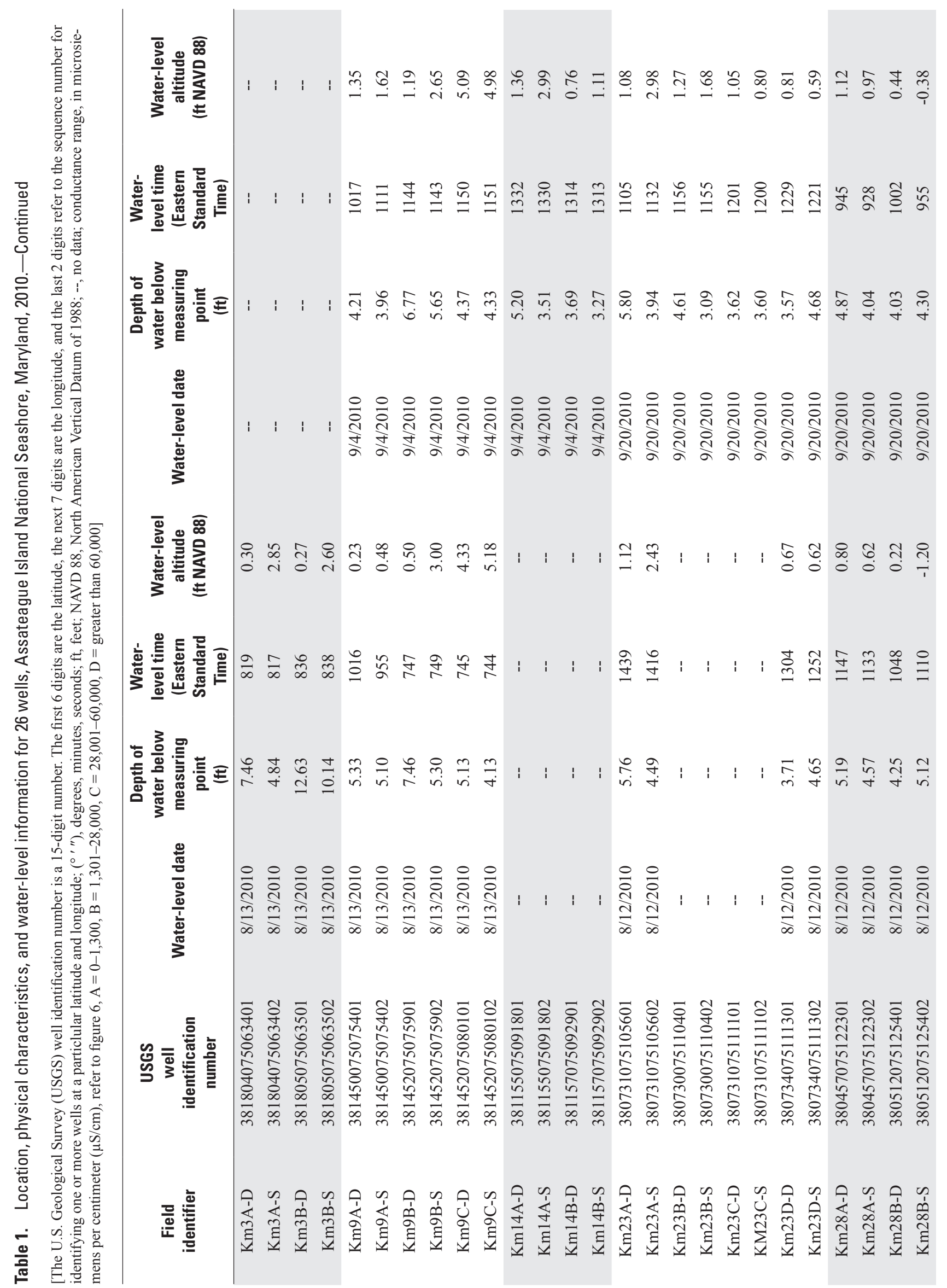




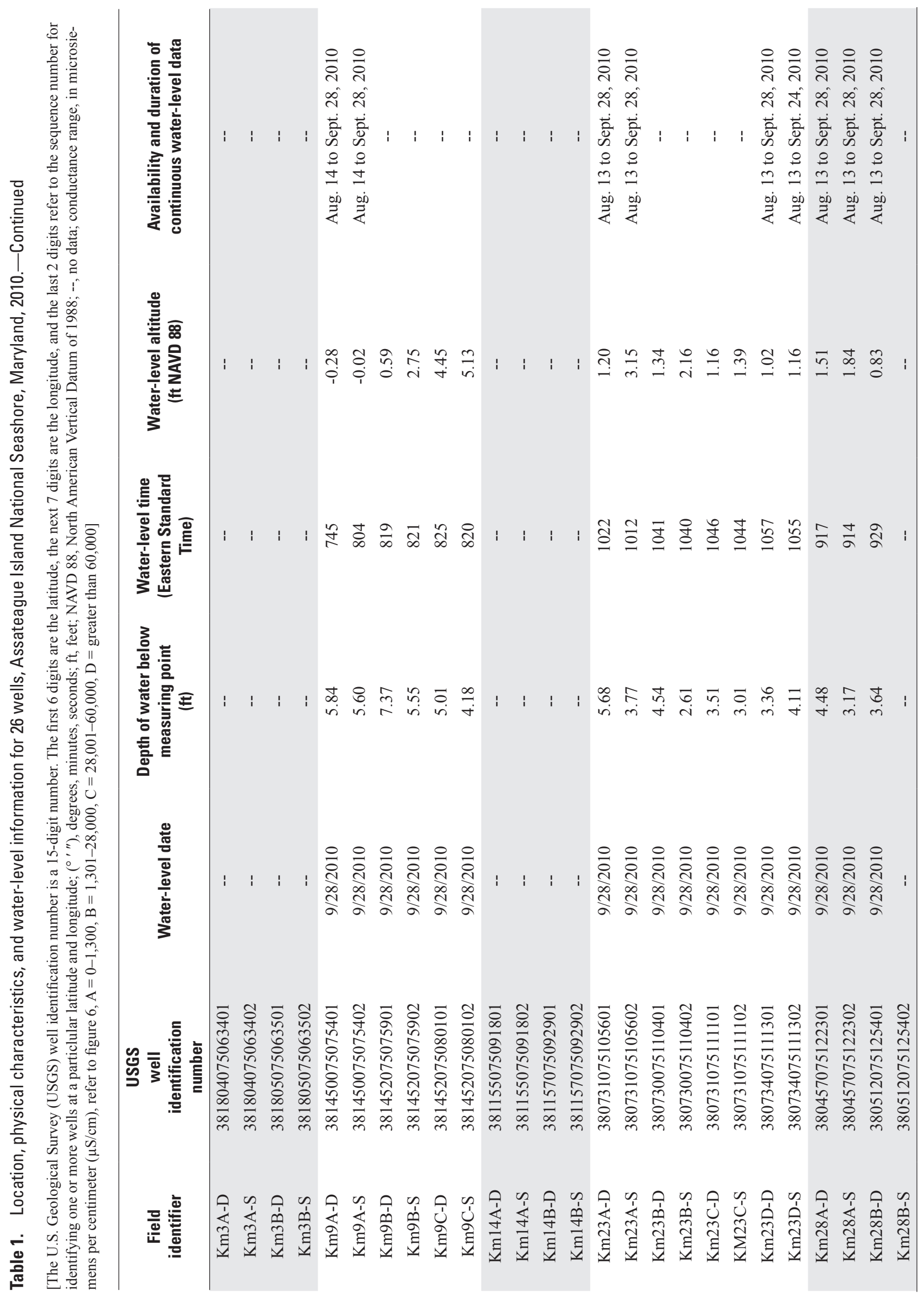


acquired using a Garmin eTrex GPS receiver with horizontal accuracy of $20 \mathrm{ft}$, and are referenced to the North American Datum of 1983 (NAD 83). Prior to drilling, all sites were field checked and approved by National Park Service (NPS) personnel to ensure that these sites were compliant with all Park permitting regulations.

Altitudes for selected wells in each transect were surveyed using a Trimble 5800 Real Time Kinematic Rover GPS receiver and were referenced to the North American Vertical Datum of 1988 (NAVD 88). Uncertainty in altitude determination for these wells ranged from 0.05 to $0.13 \mathrm{ft}$. The altitudes of all other well sites in each of the five transects were determined with a digital level using the surveyed well as a reference. Wells were surveyed to an accuracy of $0.01 \mathrm{ft}$. (table 1).

Boreholes were drilled to the desired depth using 5.625-inch (in.)-outer diameter, 2.25-in.-inner diameter, hollow-stem augers. Because only a small part of the island has paved roads, all of the wells, with the exception of those drilled along the Kilometer Marker 14 (Km14) transect, were installed with a truck-mounted CME-55 hollow-stem auger drill rig (fig. 3). This pickup-mounted drill rig allowed for greater site accessibility, but restricted the total drilling depth to less than $55 \mathrm{ft}$ at most locations. Because the area in the vicinity of the Km14 transect was paved, a truck-mounted CME-75 hollow-stem auger drill rig was used at the two well pairs along this transect.
Prior to drilling, the drill bit was sealed using a temporary polyvinyl chloride (PVC) plug to prevent aquifer material from filling the auger cavity. Wells were constructed using flush-threaded, 2-in.-diameter, schedule- $80 \mathrm{PVC}$ casing and factory-cut, 0.010-in. slot-size, 5-ft PVC screens. Once drilled to depth, well casings and screens were pre-assembled and lowered in place inside the auger annulus prior to auger removal. The well casing and screen assembly were used to dislodge the PVC plug allowing formation material to collapse around the screen and casing and hold the well in place.

Well pairs were installed along five east-west trending transects with each transect including between two and four well pairs consisting of a shallow well and a deeper well (fig. 2). Each of the shallow wells typically was screened several feet below the water table - usually in freshwater about 10 $\mathrm{ft}$ bls. Each of the deeper wells was screened below the anticipated depth to the freshwater-saltwater interface-usually in saltwater about 45 to $55 \mathrm{ft}$ bls (Krantz, 2009) (table 1).

Two nomenclature systems are used to describe the transect locations and well names. Wells were labeled in accordance with standard naming procedures described by the Maryland Department of the Environment and are based on an alphanumeric system where the first two characters (letters, both capitalized), indicate the county (in this case, WO for Worcester). The next two characters (the first capitalized, the second lower case) correspond to a 5-minute county grid

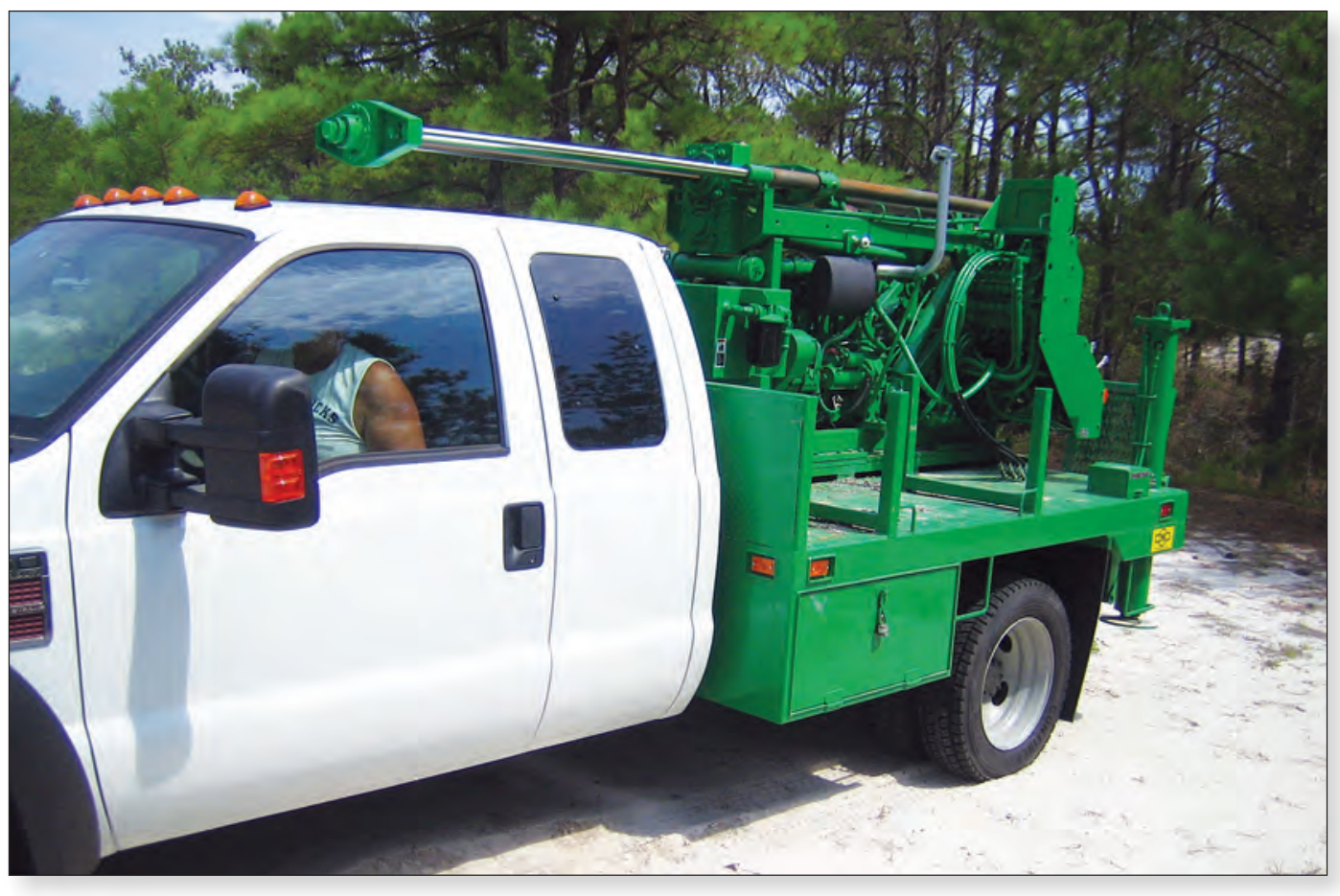

Figure 3. Truck-mounted hollow-stem auger drill rig used for monitoring well installation on Assateague Island National Seashore, Worcester County, Maryland. [Photograph by William Banks, U.S. Geological Survey, Aug. 8, 2010.] 
block. The last two characters (numbers) represent a sequence within the grid block. The second system complies with the local NPS naming conventions on Assateague Island and is based on the Kilometer Markers starting with kilometer 0 at Ocean City Inlet at the north end of the island and increasing to the south, ending at the Maryland-Virginia border. Using the second system, wells were identified first by Kilometer Marker number, then by letter sequence beginning with "A," representing the easternmost well and ending with the westernmost well ("B," "C," or "D," depending on transect). The final character denotes depth and is either a " $D$ " for deeper or an "S" for shallow (table 1).

Hydraulic connection between the newly installed wells and the surrounding aquifer material was achieved by using either compressed air or a small-volume electric pump to remove the majority of aquifer material that may have entered the well during installation, and to allow for the free flow of water between the surrounding aquifer and the well; a process typically referred to as "well development." Wells located along the Km14 transect were developed using compressed air. This method required that a volume of air under pressure (usually 100 pounds per square inch) be injected near the bottom of the well, causing a corresponding volume of water and sand to be ejected from the well head. Once evacuated, the well was allowed to recover for up to 5 minutes and the process was then repeated. The well development process was run as many times as necessary until little or no sand was ejected from the well.

For wells located along the remaining transects, a lowvolume, battery-powered pump was lowered to the bottom of the well screen and used to evacuate all of the water and sand present in the well. The well was then allowed to recover for up to 15 minutes and the process was repeated. In some cases, it was necessary to repeat this process for several days. Wells that were developed using the pump method were more likely to retain some sand material in the well despite repeated attempts at well development.

The selection of transect and well locations was based on several factors including island geomorphology, consideration of potential impact on sensitive or endangered plants and animals, and drill-rig access limitations. The four southernmost transect locations (Km9, Km14, Km23, and $\mathrm{Km} 28)$ were selected to complement previous geophysical and hydrologic data-collection efforts (Krantz, 2009).

The northernmost transect (Km3) just south of the Ocean City Inlet is in an area where the island is approximately 1,100 $\mathrm{ft}$ wide (fig. 2). This low-lying part of the island is subject to frequent and extensive overwash events, but it is also interspersed with sand dunes up to $15 \mathrm{ft}$ in height and serves as a critical location for Piping Plover nesting habitat (Jack Kumer, National Park Service, oral commun., 2010). Two well pairs were installed in an east-west transect near the center of the island along an assumed path of groundwater flow orthogonal to the long axis of the island. The "B" well pair was located near a dune crest approximately $500 \mathrm{ft}$ from Sinepuxent Bay, whereas the "A" well pair was located in a potential overwash zone approximately $500 \mathrm{ft}$ from the Atlantic Ocean. The altitude of the bottom of both shallow wells is about $7 \mathrm{ft}$ below sea level (NAVD 88), whereas the bottom of both deeper wells is about $47 \mathrm{ft}$ below sea level (NAVD 88) (table 1).

Three well pairs were installed along the transect at $\mathrm{Km} 9$, where the island is about $1,800 \mathrm{ft}$ wide. The " $\mathrm{C}$ " (westernmost) pair was installed about 1,030 ft from the ocean and about $760 \mathrm{ft}$ from Chincoteague Bay. The "B" (middle) pair was installed about $800 \mathrm{ft}$ from the Atlantic Ocean and about $1,000 \mathrm{ft}$ from Chincoteague Bay. The "A" (easternmost) pair was installed less than $400 \mathrm{ft}$ from the Atlantic Ocean, and about 1,400 ft from Chincoteague Bay. The eastern side of the island in the area where well pair Km9A is located consists of open beach and is subject to periodic overwash events. The center of the island near the location of well pair B consists of low-relief dunes and inland beach grasses, and the western side of the island near the location of well pair $\mathrm{C}$ is in an area dominated by estuarine wetlands.

The bottoms of the shallow wells in the $\mathrm{C}$ and $\mathrm{B}$ pairs are screened approximately 6 and $11 \mathrm{ft}$, respectively, below sea level (NAVD 88) whereas the bottoms of the deeper wells in the $\mathrm{C}$ and $\mathrm{B}$ pairs are screened about $45 \mathrm{ft}$ below sea level (NAVD 88). Given the proximity of well pair A to the ocean (less than $400 \mathrm{ft}$ ), the wells were installed so that only $10 \mathrm{ft}$ separates the bottom of the screens in the deeper and shallow wells - about 19 and $9 \mathrm{ft}$, respectively, below sea level (NAVD 88) (table 1).

The $\mathrm{Km} 14$ transect is located where the island is approximately 3,000 ft wide and in an area that is used for camping and other recreational activities. The wells in the A pair are located in the campground west of a manmade dune, approximately $500 \mathrm{ft}$ from the Atlantic Ocean (fig. 1). Well pair B is located in a wooded area near the center of the island, about $1,500 \mathrm{ft}$ from both Chincoteague Bay and the Atlantic Ocean (fig. 1). The bottom altitudes for the deeper wells in each well pair are between about 47 and $51 \mathrm{ft}$ below sea level (NAVD 88 ), whereas the bottom altitudes for both of the shallow wells are about $7 \mathrm{ft}$ below sea level (NAVD 88) (table 1).

The Km23 transect is located in the oldest and most stable part of the island, known as the island core (Krantz, 2009). Four well pairs were installed in this transect across the 3,400 -ft width of the island, along an existing east-west oriented access road. The altitudes of the bottom of the screened intervals for the four deeper wells range from approximately 47 to $51 \mathrm{ft}$ below sea level (NAVD 88). The altitudes of the bottom of the screened intervals of the shallow wells were all approximately $8 \mathrm{ft}$ below sea level (NAVD 88 ).

The Km28 transect consists of two well pairs located along an existing access road in the widest part (nearly $7,100 \mathrm{ft}$ ) of the island core. The altitude of the bottom of the screened interval of the deeper well of the B (westernmost) well pair is about $49 \mathrm{ft}$ below sea level (NAVD 88). The deeper well in the A well pair is about $44 \mathrm{ft}$ below sea level (NAVD 88). The altitudes of the bottom of the shallow well screens in the two well pairs are approximately $9 \mathrm{ft}$ below sea level (NAVD 88) (table 1). 


\section{Hydrogeologic Data Collection}

Hydrogeologic data collected during this study included water levels and borehole geophysical logs. Periodic manual measurements were made at all 26 of the monitoring wells; 9 of these wells ( 4 shallow and 5 deeper) were instrumented for continuous water-level data recording during a 7-week period between August 12 and September 28, 2010. Borehole geophysical logs were collected from the 13 deeper wells to characterize changes in lithology and salinity in the shallow groundwater flow system.

\section{Water Levels}

Water levels were measured at least two or three times in each monitoring well between August 12 and September 28, 2010. The number of measurements was dependent upon site access due to changing weather and beach conditions (table 1). In order to measure the altitude of water levels relative to a fixed datum, a permanent measuring point referenced to sea level (NAVD 88) was established on the top of each well casing. The height above land surface for each measuring point is listed in table 1. Water-level altitudes in all of the observation wells were then calculated by subtracting the depth to water from the altitude of the permanent measuring point. These measurements were then recorded to the nearest $0.01 \mathrm{ft}$ (table 1).

Continuous water-level measurements are useful for determining the potential influences of changes in precipitation and tides on water levels both in terms of the magnitude and timing of any potential response. Nine of the 26 wells were instrumented with vented pressure transducers (In-Situ Troll 500s and In-Situ Aqua Troll 200s) to record water levels continuously at 15 -minute intervals during the 7 -week period. Water levels were not corrected to account for density differences due to saltwater, and all transducers were calibrated prior to deployment to a water density of 0.999 grams per cubic centimeter $\left(\mathrm{g} / \mathrm{cm}^{3}\right)$ (table 1$)$.

The four instrumented shallow wells included the A series wells at $\mathrm{Km} 9, \mathrm{Km} 23$, and $\mathrm{Km} 28$ and the D series wells at Km23. The five instrumented deeper wells included the same well series as the instrumented shallow wells and also the deeper well at Km28B. These wells were selected because of their proximity to the ocean and, in the case of the wells at $\mathrm{Km} 23 \mathrm{D}$, to Chincoteague Bay, to determine how tides may affect water levels in these areas. Tides around Assateague Island exhibit semi-diurnal or daily cycles (two high and two low tides daily) and lunar cycles that vary bi-weekly and exhibit a relative maxima (spring tide) and relative minima (neap tide). Intermittent manual water-level measurements also were collected from these wells to verify the accuracy of the data recorders.

Water levels collected at each of the continuously measured monitoring wells were plotted along with tide data from the National Oceanic and Atmospheric Administration's Ocean
City Inlet, Md. tide gage (station 8570283) and precipitation data from a weather station operated by NPS personnel at Assateague Island National Park headquarters, 1 mile west of the island (Brian Sturgis, National Park Service, written commun., 2010), in order to illustrate the factors that may affect the change in water levels over time in both the shallow and deeper flow systems. An analysis of these data indicates that tidal fluctuations of as much as $3 \mathrm{ft}$ appear to have a minor influence on inland water levels as shown by the small perturbations (water-level changes less than $0.1 \mathrm{ft}$ ) in the hydrographs for both the shallow and deeper wells (figs. 4 and 5). This influence did not appear to differ across the island from the ocean to the bay as shown by the similar lack of waterlevel response at well pair Km28A (fig. 4).

The largest effect on water levels in all of the shallow wells where continuous data were collected appeared to be the periodic precipitation events that occurred throughout the measurement period. Increases in water levels in these wells were directly related to the amount of precipitation that occurred during this period. The largest precipitation event occurred on August 18, 2010 and resulted in waterlevel increases of about $0.7 \mathrm{ft}$ in response to the nearly $1.8 \mathrm{in}$. of precipitation. However, the largest water-level increases observed during the measurement period were observed in the shallow wells at both the Km9A and $\mathrm{Km} 23 \mathrm{~A}$ sites (1.24 and $1.44 \mathrm{ft}$, respectively) and occurred on September 3, 2010 after a precipitation event of only $0.34 \mathrm{in}$. These anomalously high water-level increases were most likely the result of overland flooding produced by a storm surge that allowed for rapid infiltration down the well annulus, causing a spike in water levels at these two sites-a response that was not observed at the other well transects.

Because the data-collection period was about 7 weeks, it was also possible to partly assess potential longer-term astronomical and meteorological effects on the groundwater system. The sinusoidal change in tidal elevation over the measurement period represents a change in the ambient sea-level position that was most likely the result of building onshore flow generated by changes in the prevailing wind field from passing weather systems. Daily tidal amplitude did not vary over this time period and indicated that spring and neap tide influences are negligible.

The plots of the continuous water levels in the shallow wells do not show effects from these longer-term astronomical and meteorological conditions/events compared to the short duration precipitation and daily tidal events. However, the water levels in the deeper wells did appear to be influenced by changes in ambient sea level over the measurement period. This effect was most notable from September 18-22, 2010, when a rise in water levels was observed with no corresponding precipitation event. This water-level rise appeared to coincide with an increase in the ambient sea level that was most likely the result of building onshore flow, which is consistent with water-level changes observed in a hydrogeologically similar groundwater system on Fire Island, N.Y. (Schubert, 2010). 


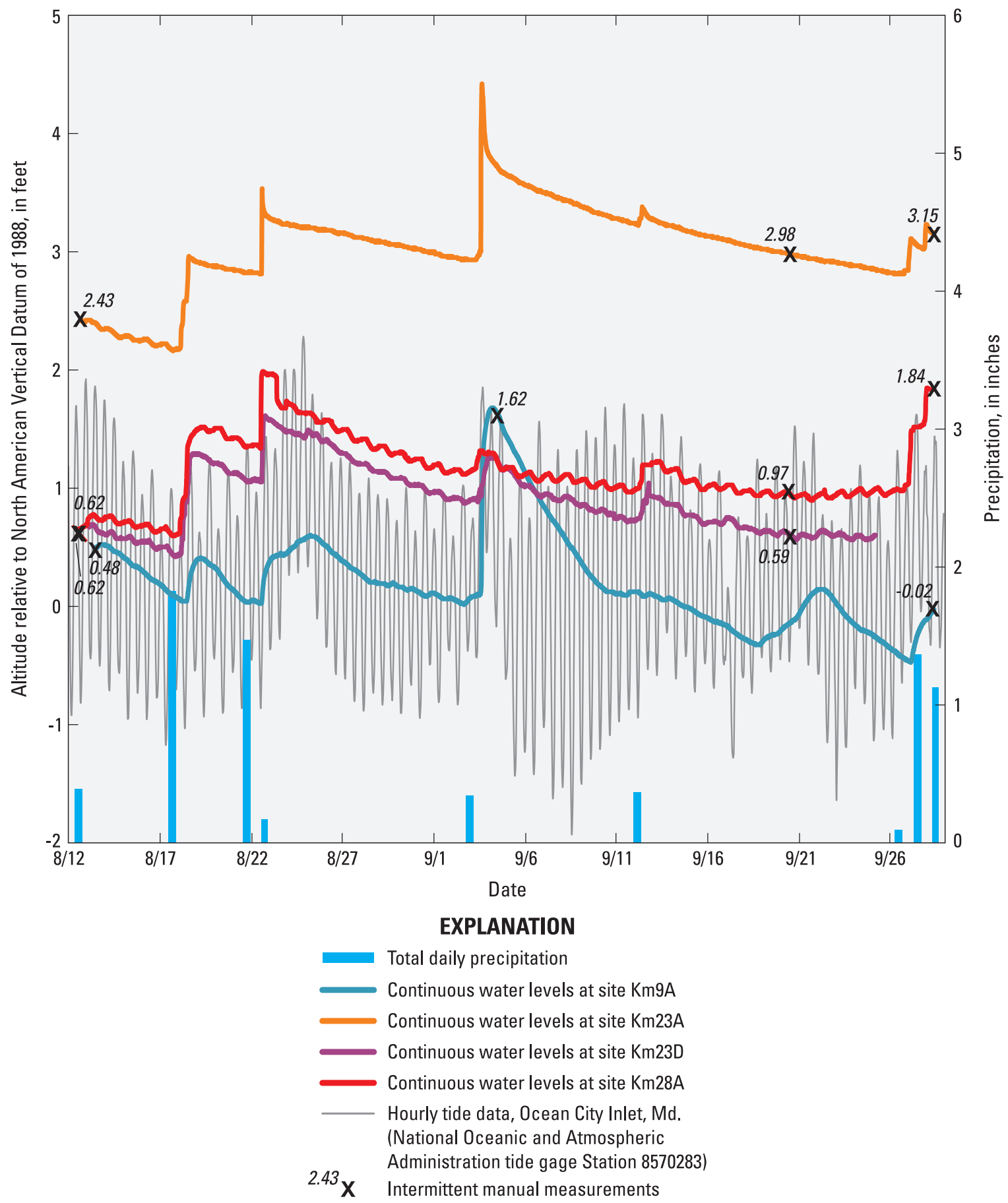

Figure 4. Continuous water-level data, intermittent manual measurements, tide altitude data, and total daily precipitation data for the shallow monitoring wells at Km9A, Km23A, Km23D, and Km28A from August 12 to September 28, 2010, Assateague Island National Seashore, Maryland. [Tide data from National Oceanic and Atmospheric Administration, 2010; precipitation data from Brian Sturgis, National Park Service, written commun., 2010.] 


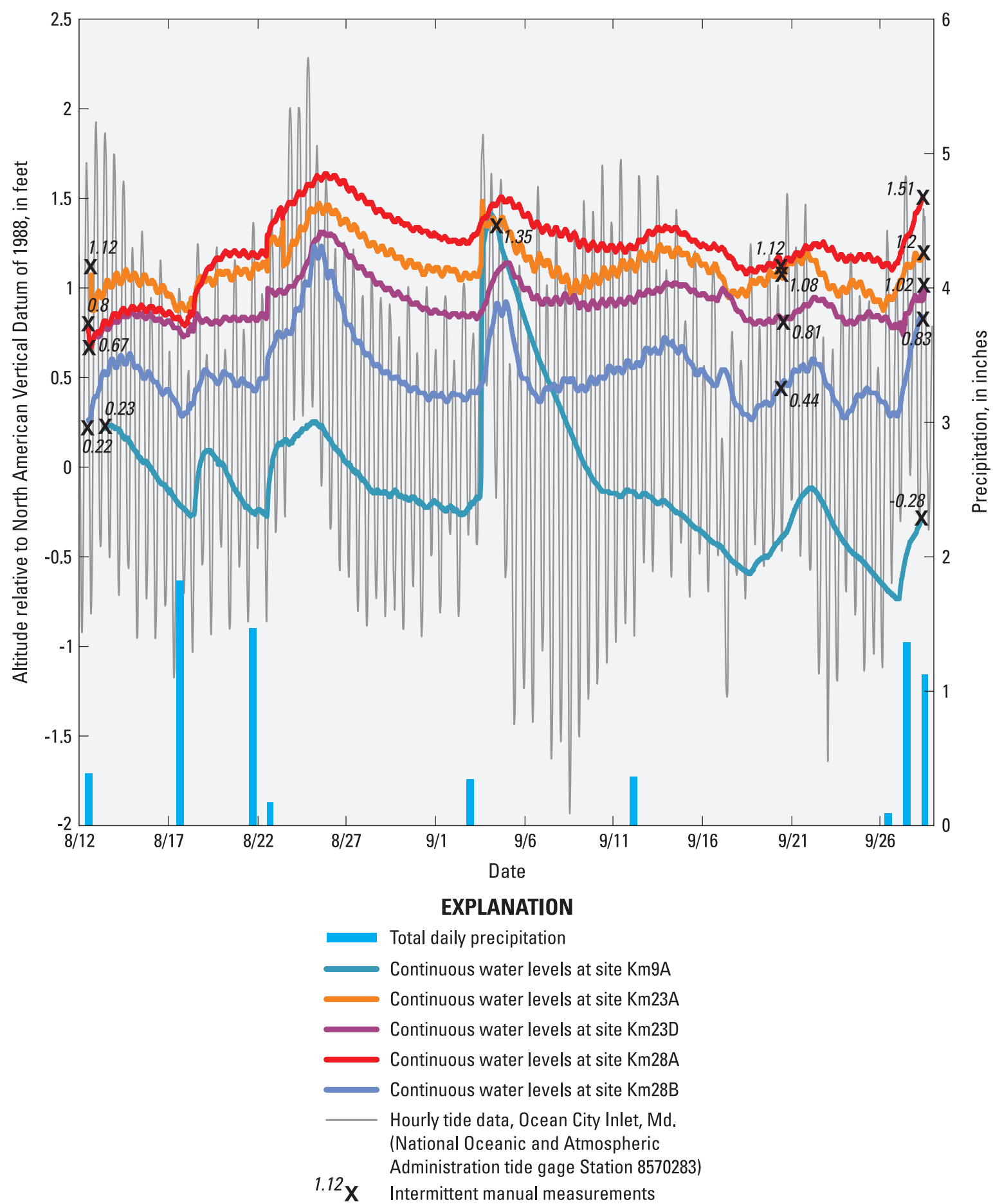

Figure 5. Continuous water-level data, intermittent manual measurements, tide altitude data, and total daily precipitation data for the deeper monitoring wells at Km9A, Km23A, Km23D, Km28A, and Km28B from August 12 to September 28, 2010, Assateague Island National Seashore, Maryland. [Tide data from National Oceanic and Atmospheric Administration, 2010; precipitation data from Brian Sturgis, National Park Service, written commun., 2010.] 
Although the water levels in the deeper wells all appeared to be influenced by changes in the ambient sea level, and to a lesser extent, precipitation events, the extent to which water levels were affected varied among the sites, indicating that changes in lithology and salinity also may affect groundwater flow across the island and between the shallow and deeper parts of the flow system. An example of the differences in the flow systems of the shallow wells and deeper wells is most apparent at the $\mathrm{Km} 23 \mathrm{~A}$ well pair, where the shallow well is mainly influenced by precipitation and periodic overland flooding, such as the event that occurred on September 4, 2010; the deeper well showed a minor response to precipitation, but appears to have been more affected by changes in the ambient sea level (figs. 4 and 5). In contrast, there appears to be no difference in the response of water levels between the shallow and deeper wells at Km9A (fig. 5), which may be caused by the small vertical distance $(10 \mathrm{ft})$ between these well screens compared to the $40-\mathrm{ft}$ difference at $\mathrm{Km} 23 \mathrm{~A}$ (table 1).

\section{Borehole Geophysical Logging}

Natural gamma and electromagnetic induction (EMI) logs were collected at each of the 13 deeper wells installed along the 5 transects to help characterize changes in the aquifer material and the transition between fresh and saltwater in the shallow groundwater flow system. Gamma logging measures the natural-gamma radioactivity of the material surrounding the borehole (Keys, 1990). The most significant, naturally occurring sources of gamma radiation are potassium- 40 and daughter products of uranium and thorium decay series. Gamma emissions can commonly be correlated with sediment type in unconsolidated materials such as those found at ASIS. Potassium- 40 is abundant in some feldspar and mica, and uranium and thorium can be concentrated by geochemical processes. Gamma logs are typically recorded in counts per second at $0.1-\mathrm{ft}$ intervals.

Deviations in the gamma log indicate changes in lithology or the presence of altered zones or mineralization. The vertical resolution of the gamma probe is generally 1 to $2 \mathrm{ft}$, and the probe is able to detect gamma radiation through plastic and steel casing. Because the gamma log does not have a unique lithologic response, interpretation must be correlated with other information such as drilling logs and descriptions of geologic cores and cuttings where available as well as other geophysical logs. In general, clays and silts have higher gamma counts than sands and gravels.

EMI logging records the electrical conductivity of the sediment and the fluids in the sediment surrounding the borehole (Williams and others, 1993). Changes in electrical conductivity are caused by variations in porosity, borehole diameter, the concentration of dissolved constituents in the pore fluid, and the amount of metallic minerals. The EMI logging tool is most sensitive to the aquifer material and pore water approximately $1 \mathrm{ft}$ away from the probe, and the tool has a vertical resolution of approximately $2 \mathrm{ft}$. In boreholes with diameters of 6 in. or less, the conductivity of the borehole fluids has a negligible effect on the induction log response. The full-tool response is about $10 \mathrm{ft}$ in thickness, which means that it requires a 10 -ft-thick zone to get a true conductivity measurement of the formation. If there is a narrow layer (less than $10 \mathrm{ft}$ thick) and it is sufficiently conductive, it may be detected, but the actual conductivity of that layer will be greater than what is measured with the tool. The tool response of thin conductive zones (less than $1.6 \mathrm{ft}$ thick) is expected to be less than half of the zone's true conductivity (Taylor and others, 1989). For this investigation, EMI conductivity was recorded in millisiemens per meter $(\mathrm{mS} / \mathrm{m})$ at $0.1-\mathrm{ft}$ intervals. The tool was calibrated to $465 \mathrm{mS} / \mathrm{m}$ and to air $(0 \mathrm{mS} / \mathrm{m})$ at the time of logging. The EMI tool was allowed to thermally equilibrate prior to calibration and logging.

The EMI log was used to delineate changes in the aquifer materials and (or) changes in electrical properties of pore water (for instance, to identify freshwater or saltwater). In freshwater, clays and silts generally have higher electrical conductivity than the EMI conductivity of sands and gravels. However, if the sand or gravel unit is saturated with a highly conductive fluid, such as brackish or saltwater, then the EMI conductivity of the coarse material can have a higher EMI conductivity value than that of the fine materials. Because of this complexity, the gamma and EMI logs were interpreted together to determine whether increased EMI conductivity is likely caused by the presence of clay and silt or by electrically conductive water. In addition, specific conductance (SC), temperature, and water-level values were collected in both the shallow and deeper wells to help interpret the borehole logs and identify the source of the conductivity. Since the wells had been developed prior to the borehole logging, the water in the wells was thought to be generally representative of the screened interval, which was in the lowermost $5 \mathrm{ft}$ of the boreholes. To confirm this theory/assumption, $\mathrm{SC}$ was measured in several places over the length of the screened interval to verify that the water in the well was not stratified.

A comparison of the natural gamma and EMI logs collected at the 13 deeper wells in the 5 transects provides the information necessary to characterize changes in aquifer material and determine both the extent of the shallow freshwater lens and the presence of a deeper freshwater flow system underlying Assateague Island. All logs were converted from depth below top of casing to altitude for easier comparison. Natural gamma and EMI data can be used to better understand the water-level changes observed in the shallower and deeper parts of the groundwater flow system over time (figs. 6a-e).

\section{Profile at Km3}

The well transect at $\mathrm{Km} 3$ is shown in the form of a profile with 3B on the west (left) and 3A on the east (right) (fig. 6a and fig. 2). The $\mathrm{SC}$ measurement collected at the time of logging in Km3B-S was freshwater (1,340 microsiemens per centimeter at 25 degrees Celsius or $\mu \mathrm{S} / \mathrm{cm}$ ), and the $\mathrm{SC}$ 
in $\mathrm{Km} 3 \mathrm{~B}-\mathrm{D}$ was mildly conductive $(10,400 \mu \mathrm{S} / \mathrm{cm})$. In both wells $\mathrm{Km} 3 \mathrm{~B}$ and $\mathrm{Km} 3 \mathrm{~A}$, the EMI logs showed an increase in EMI conductivity at an altitude of $0 \mathrm{ft}$ and another increase at an altitude at about $-25 \mathrm{ft}$, where there was also an increase in gamma counts. The increase in gamma is interpreted as a change in lithology from sand to finer sand, silt, or clay. The gamma counts were fairly uniform from $-25 \mathrm{ft}$ to the bottom of the boreholes. However, in the bottom of the boreholes, EMI conductivity declined from an altitude of about $-35 \mathrm{ft}$ to the bottom of the holes, indicating that this change in conductivity is water-related. Although the EMI and gamma patterns were fairly similar in wells $\mathrm{Km} 3 \mathrm{~B}$ and $\mathrm{Km} 3 \mathrm{~A}$, the SC measurements were different. The SC in the shallow well at Km3A-S was moderately conductive at $25,300 \mu \mathrm{S} / \mathrm{cm}$ (more conductive than 3B-S), and the water in Km3A-D was fresh $(1,410$ $\mu \mathrm{S} / \mathrm{cm})$. The gamma logs were fairly consistent between wells $\mathrm{Km} 3 \mathrm{~B}$ and $\mathrm{Km} 3 \mathrm{~A}$ and may indicate the presence of a fairly continuous low-permeability layer. These results, along with anecdotal evidence that this location is prone to overwash events, are consistent with the infiltration of saltwater downward into an aquifer consisting of sand that overlies a more electrically conductive formation with fine sands and silts with conductive water, that in turn, overlies freshwater.

\section{Profile at $\mathrm{Km} 9$}

The profile at $\mathrm{Km} 9$ is shown in figure $6 \mathrm{~b}$ with $\mathrm{Km} 9 \mathrm{C}$ on the west (left) and Km9A on the east (right) (fig. 6b). The $\mathrm{SC}$ in the well pair at 9C indicated highly conductive water $(56,700 \mu \mathrm{S} / \mathrm{cm})$ in the shallow well and freshwater $(1,100$ $\mu \mathrm{S} / \mathrm{cm})$ in the deeper well. The $\mathrm{SC}$ in the well pair at $9 \mathrm{~B}$ had a moderately high SC $(36,100 \mu \mathrm{S} / \mathrm{cm})$ in the shallow well and freshwater $(810 \mu \mathrm{S} / \mathrm{cm})$ in the deeper well. The well pair at 9A had moderately conductive water in the shallow well $(18,200$ $\mu \mathrm{S} / \mathrm{cm})$ and very high SC $(65,000 \mu \mathrm{S} / \mathrm{cm})$ in the deeper well, which is not that much deeper than the shallow well at 9B. Collectively, these SC measurements indicate increased SC in the shallow to mid-range depths and freshwater at depth.

In the uppermost sections of the Km9 wells, the gamma counts were fairly low, which is consistent with the presence of medium- to coarse-grained sand, and the EMI conductivity showed minor increases at altitudes of $+2,-5$, and $-4 \mathrm{ft}$ in wells $\mathrm{Km} 9 \mathrm{C}$, Km9B, and Km9A, respectively. In each of the well pair locations, the increase in EMI conductivity occurred at altitudes higher than the increase in gamma emissions, indicating that the increase in EMI conductivity is fluidrelated, which is consistent with the SC values in the wells. The gamma logs for all three wells along this profile are fairly similar and show increases in gamma counts at altitudes of about $-8,-12$, and $-15 \mathrm{ft}$ (in wells 9C, 9B, and 9A, respectively). This increase in gamma counts is likely caused by the presence of fine sand, silt, and (or) clay.

There are segments in the gamma logs that have patterns that can be traced in the logs of other nearby boreholes. One segment shows a decrease in gamma counts in well $\mathrm{Km} 9 \mathrm{C}$ at an altitude of $-22 \mathrm{ft}$, and is similar in shape and magnitude to a decrease in gamma counts in well Km9B at -24 ft. This zone, which is likely a layer of relatively coarser material (sand), also coincides with the gradual decline in EMI conductivity in wells $\mathrm{Km} 9 \mathrm{C}$ and $\mathrm{Km} 3 \mathrm{~B}$. Although the gamma counts increase slightly below the coarse material, the EMI conductivity values remain low in both wells, which is consistent with the presence of freshwater at depth. Collectively, these results indicate the presence of freshwater in the uppermost sand that overlies saltwater in the fine-grained sands or silts that extend to about -20 to $-25 \mathrm{ft}$. Below an altitude of $-24 \mathrm{ft}$, the materials are likely sand and silts with freshwater. A comparison of the EMI and gamma logs collected in wells Km 9C, 9B, and 9A shows that they are fairly similar, indicating that the lithology is somewhat continuous across the well transect.

\section{Profile at Km14}

The profile at $\mathrm{Km} 14$ is shown in figure $6 \mathrm{c}$ with $\mathrm{Km}$ 14B on the west (left) and Km14A on the east (right) (fig. 6c). The $\mathrm{SC}$ collected in the well pair at Km14B at the time of logging showed freshwater $(630 \mu \mathrm{S} / \mathrm{cm})$ over highly conductive saltwater $(60,300 \mu \mathrm{S} / \mathrm{cm})$ in the deeper well. The SC collected in the Km14A well pair showed freshwater $(305 \mu \mathrm{S} / \mathrm{cm})$ over highly conductive saltwater $(50,300 \mu \mathrm{S} / \mathrm{cm})$ in the deeper well. The EMI logs show gradual increases in conductivity starting at an altitude of about $-10 \mathrm{ft}$ in wells Km14B and $\mathrm{Km}$ 14A. The gamma logs in these boreholes show fairly abrupt increases in gamma emissions at an altitude of about $-12 \mathrm{ft}$, indicating the presence of fine materials. The gamma $\log$ in well $\mathrm{Km} 14 \mathrm{~A}$ also shows a $3-\mathrm{ft}$ zone at an altitude of about -37 to $-40 \mathrm{ft}$ with a slightly lower gamma count and a corresponding break in slope and reduction in EMI conductivity, which was likely caused by a sandy layer. A similar decline in EMI conductivity is observed at the same depth in well $\mathrm{Km} 14 \mathrm{~B}$, but with a less defined gamma signature.

In general, the gamma and EMI logs along the Km14 profile are fairly consistent, and layers that can be observed in both may be horizontal. Although the gamma and EMI logs indicate a change in the lithology from relatively coarser material at the surface to finer material [fine sand, silt, and (or) clay] at depth, the SC data indicate these changes are also water-related, as there is freshwater in the shallow wells over saltwater in the deeper wells. This distribution of materials and fluid conductivities is consistent with a freshwater lens derived from precipitation overlying salty groundwater.

\section{Profile at Km23}

The well transect at $\mathrm{Km} 23$ is shown in figure $6 \mathrm{~d}$ with $\mathrm{Km} 23 \mathrm{D}$ on the west (left) and $\mathrm{Km} 23 \mathrm{~A}$ on the east (right) (fig. 6d). The $\mathrm{SC}$ collected at the time of logging in well $\mathrm{Km} 23 \mathrm{D}$ showed freshwater (less than $1,420 \mu \mathrm{S} / \mathrm{cm}$ ) in the shallow well. The shallow wells at $\mathrm{Km} 23 \mathrm{C}$, B, and A had slightly to moderately elevated SC (from 4,300 to 31,700 $\mu \mathrm{S} / \mathrm{cm}$ ) indicating infiltration of salty surface water, which 
may be caused by periodic overwash events from storm surges. In the deeper wells (at altitudes of about $-45 \mathrm{ft}$ ), all four wells had saltwater (greater than $64,000 \mu \mathrm{S} / \mathrm{cm}$ ) at depth (fig. 6d). An increase in the EMI conductivity coincides with an increase in gamma counts, which together are consistent with a change in lithology from sand to fine materials (fine sand, silt, clay) at about 20 to $23 \mathrm{ft}$ bls.

The EMI log in well Km23A was different from those in the other wells in the shallowest part of the aquifer. This log showed an increase in EMI conductivity from -2 to $-7 \mathrm{ft}$ altitude, which was consistent with a high $\mathrm{SC}$ value observed in wells Km23A-S. One possible explanation could be that brackish water was introduced through the well annulus. A mechanism for this process would be overwash from a nearby pond of unknown conductivity. It is unlikely (but not impossible) that this site experienced overwash from ocean water as the site is about $800 \mathrm{ft}$ from the Atlantic Ocean. The EMI and gamma logs in well KM23A below this shallow conductive zone were fairly similar to those from the other wells along the profile. In the Km23D, C, B, and A profiles, the gamma logs show an increase in the gamma counts at an altitude of -22 to $-27 \mathrm{ft}$. This increase in gamma counts is interpreted as an increase in fine-grained materials. Other minor decreases in gamma counts from about -35 to $-40 \mathrm{ft}$ may indicate the presence of a coarser or sandy layer similar to that observed in wells Km23C, B, and A. The EMI logs in wells Km23D, C, and $\mathrm{B}$ decrease at about $-38 \mathrm{ft}$. The similarities in the EMI and gamma logs indicate that the layers are fairly continuous and level.

Collectively, the logs indicate that along the transect at $\mathrm{Km} 23$, there is either sand and freshwater or sand and brackish water at shallow depths, overlying finer-grained materials with highly conductive water from altitudes starting at about -22 to $-25 \mathrm{ft}$ and extending to the bottom of the boreholes at an altitude of about $-48 \mathrm{ft}$. There was no freshwater found at depth in these boreholes that might indicate the presence of a regional groundwater flow system. Surface geophysics suitable for deeper imaging or a deeper well would be needed to estimate or measure the conductivity below the depths of these boreholes.

\section{Profile at Km28}

The well transect at $\mathrm{Km} 28$ is shown in figure 6e with $\mathrm{Km} 28 \mathrm{~B}$ on the west (left) and $\mathrm{Km} 28 \mathrm{~A}$ on the east (right) (fig. 6e). The SC collected at the time of logging in $\mathrm{Km} 28 \mathrm{~B}$ indicated freshwater $(775 \mu \mathrm{S} / \mathrm{cm}$ ) over saltwater (greater than $100,000 \mu \mathrm{S} / \mathrm{cm}$ ). This is consistent with findings by Krantz (2009) that indicate the groundwater is highly dynamic, ranging from freshwater to saltwater with respect to episodic overwash events (Krantz, 2009). The SC in the well pair in $\mathrm{Km} 28 \mathrm{~A}$ indicates freshwater $(185 \mu \mathrm{S} / \mathrm{cm})$ over moderately conductive $(25,500 \mu \mathrm{S} / \mathrm{cm})$ water. The EMI log in $\mathrm{Km} 28 \mathrm{~B}$ shows a fairly gradual increase in the conductivity starting from an altitude of $-15 \mathrm{ft}$ and increasing to the bottom of the borehole. The gamma log shows a minor increase in counts at an altitude of about $-16 \mathrm{ft}$, indicating a change in the aquifer materials from coarser to finer. The increase in EMI conductivity in $\mathrm{Km} 28 \mathrm{~A}$ is coincident with an abrupt increase in the gamma counts at an altitude of about $-24 \mathrm{ft}$. The EMI conductivity decreases at the same location where the gamma decreases at altitudes of about -35 to $-39 \mathrm{ft}$, indicating the presence of a medium- to coarse-grained sand layer. Below this sand (or relatively coarser) layer, the gamma count increases and the EMI conductivity continues to decline; however, the EMI log from the deeper well at Km28A indicates there is conductive water at depth. Collectively, the logs in this profile indicate that there is a freshwater sand layer overlying fine materials and saltwater at the depths of these boreholes. Deeper drilling or deep-imaging surface geophysical logging at this location would be necessary in order to determine the presence of the regional freshwater groundwater flow system possibly observed in the profiles in the northern part of Assateague Island.

\section{Consideration for Additional Investigation}

The results of this investigation show a need for further study. A comparison of the natural gamma and EMI logs collected at the 13 deeper wells in all 5 transects, along with measurements of SC, could provide information that is useful in characterizing changes in aquifer material and determining the extent of the shallow freshwater lens underlying Assateague Island as characterized in this investigation. Installation of a deeper borehole or deep-imaging surface geophysical methods would be needed to identify the presence of a deeper freshwater system and to support more in-depth lithologic interpretations. Results of this investigation show the need for the collection of continuous water-level data in both the shallow and deeper parts of the flow system, and analysis of EMI and natural gamma geophysical logging data to better understand the response of this groundwater system to changes in precipitation and tidal forcing. Hydrologic data collected as part of this investigation will serve as the foundation for the development of numerical flow models to assess the potential effects of climate change on groundwater flow in the shallow aquifer system of Assateague Island. 
$\mathrm{Km} 3 \mathrm{~B}$

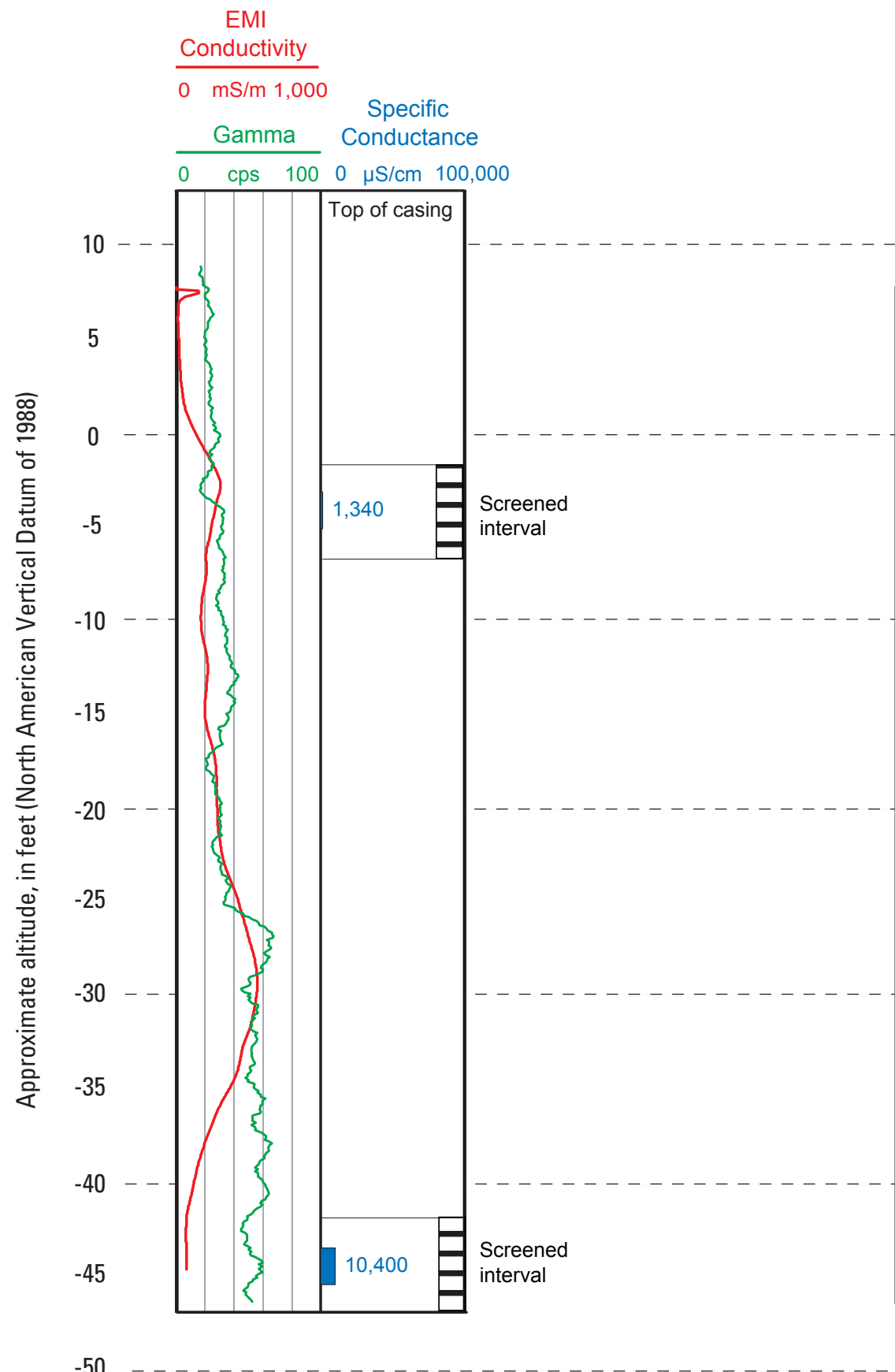

$\mathrm{Km} 3 \mathrm{~A}$

EMI Conductivity

$0 \mathrm{mS} / \mathrm{m} 1,000$

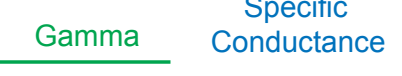

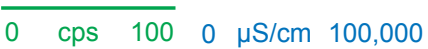




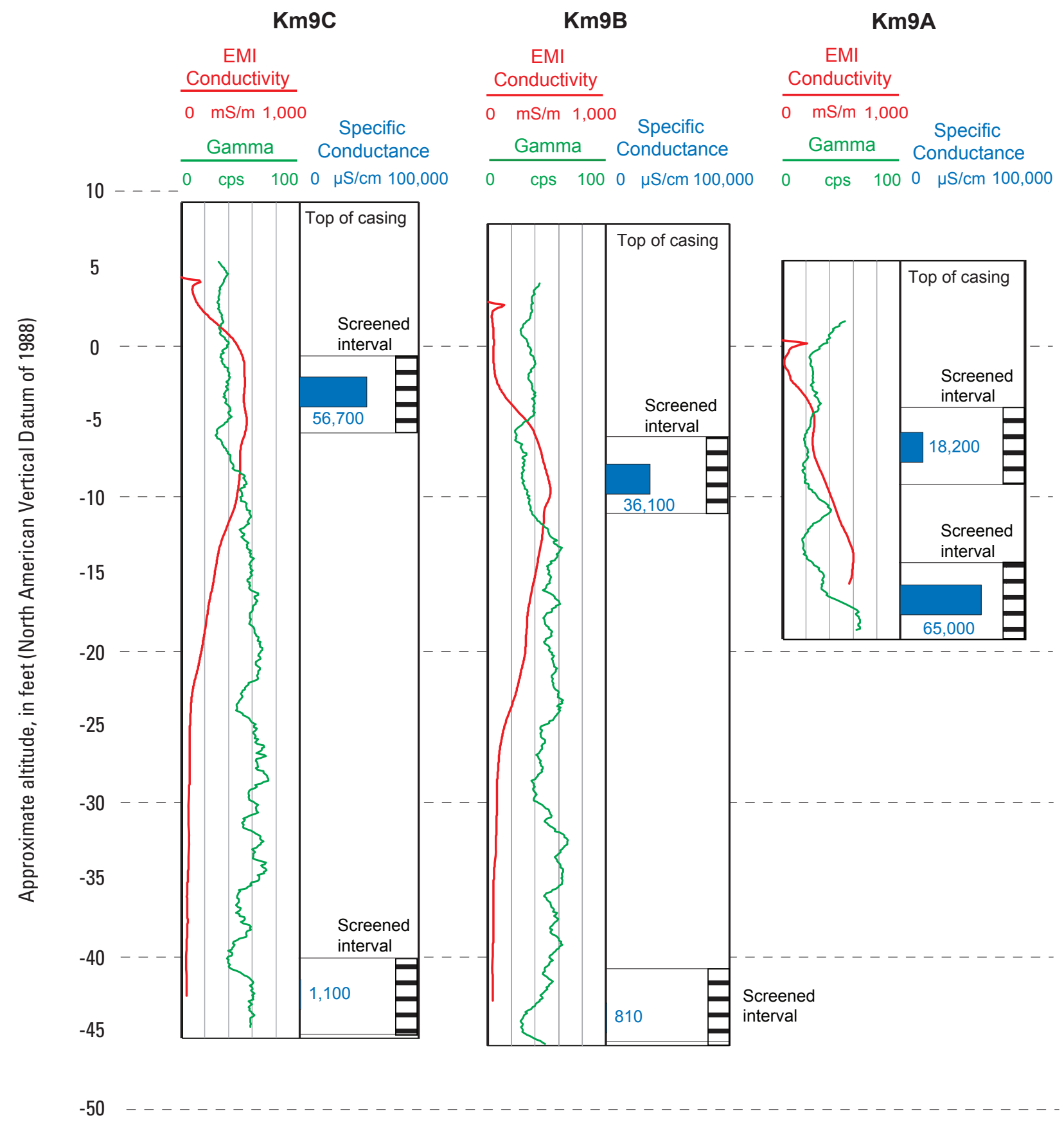

Figure 6b. Natural gamma and electromagnetic induction logs collected at transect Km9, Assateague Island National Seashore, Maryland [Electromagnetic induction (EMI) conductivity was collected in millisiemens per meter $(\mathrm{mS} / \mathrm{m})$; natural gamma in counts per second (cps); specific conductance in microsiemens per centimeter $(\mu \mathrm{S} / \mathrm{cm})$ at 25 degrees Celsius with the numeric value shown next to the blue scale bar; black and white striped box indicates the location of the screened interval]. 
Km14B

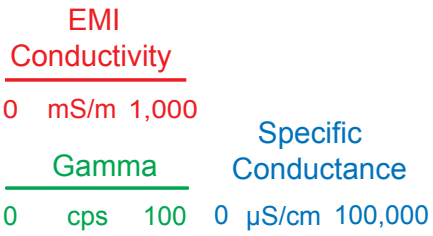

$\mathrm{Km} 14 \mathrm{~A}$

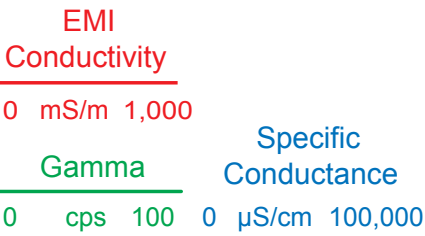

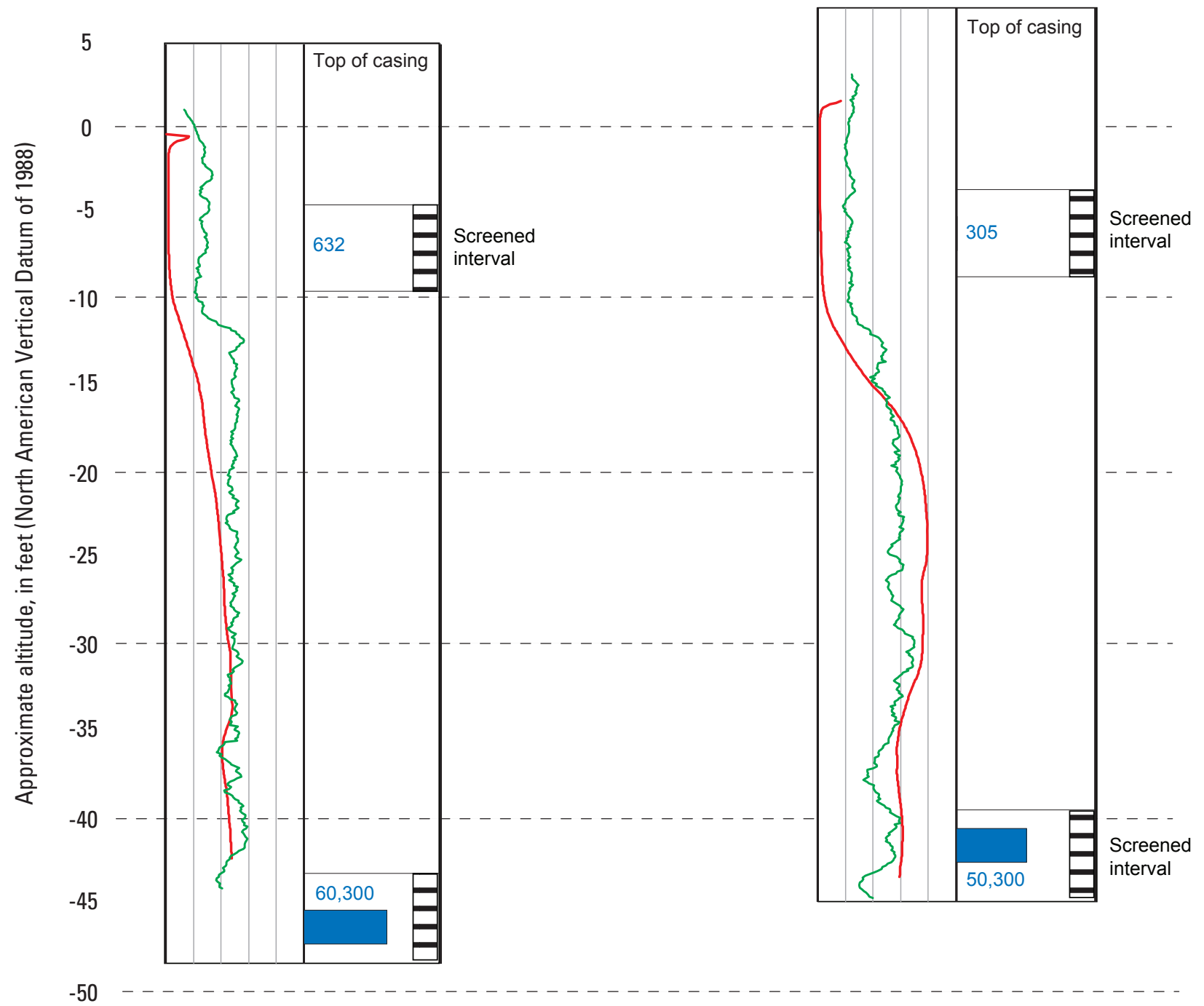

Figure 6c. Natural gamma and electromagnetic induction logs collected at transect Km14, Assateague Island National Seashore, Maryland [Electromagnetic induction (EMI) conductivity was collected in millisiemens per meter $(\mathrm{mS} / \mathrm{m})$; natural gamma in counts per second (cps); specific conductance in microsiemens per centimeter $(\mu \mathrm{S} / \mathrm{cm})$ at 25 degrees Celsius with the numeric value shown next to the blue scale bar; black and white striped box indicates the location of the screened interval]. 
Km23D

$\mathrm{Km} 23 \mathrm{C}$

Km23B

Km23A
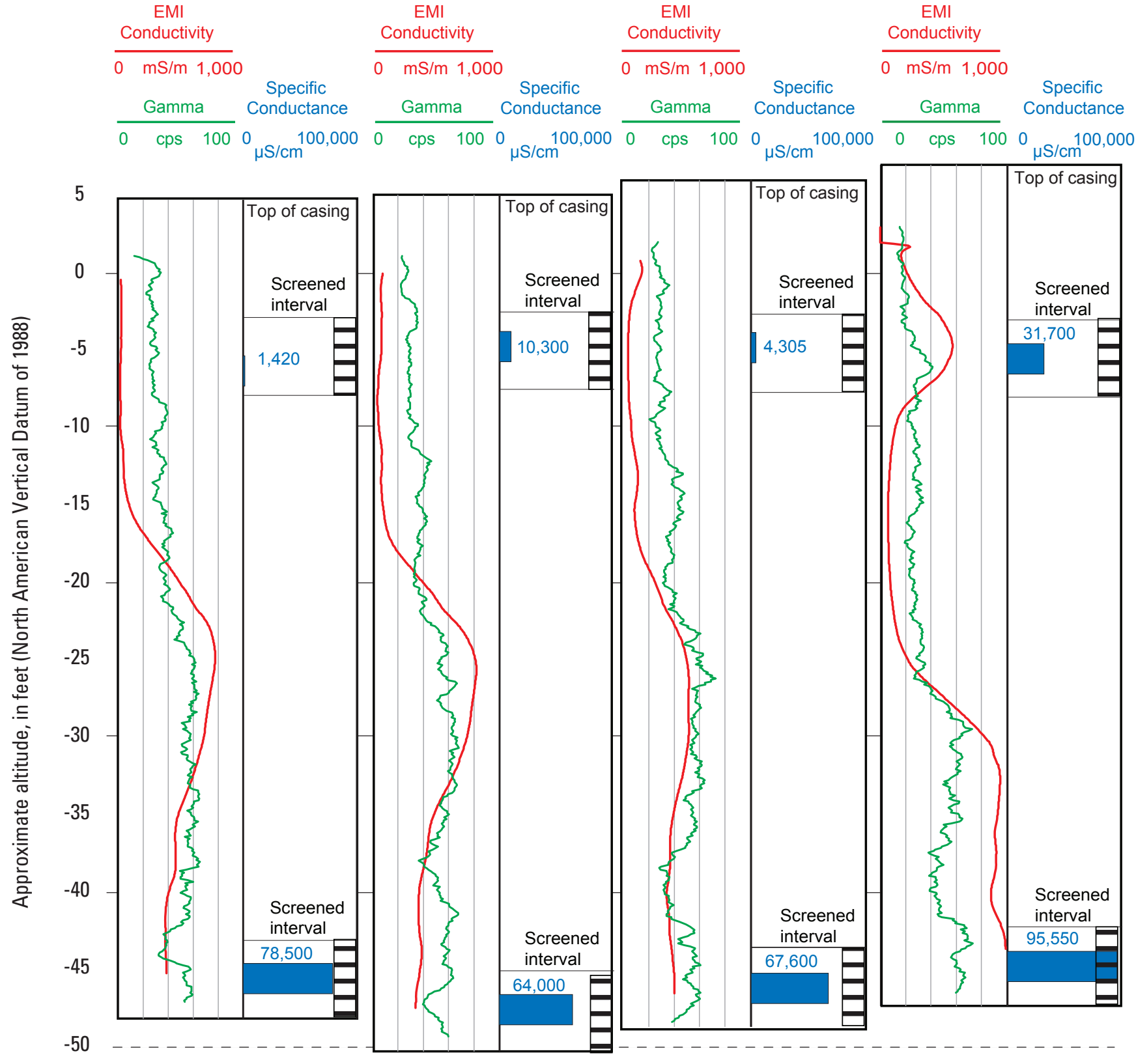

Figure 6d. Natural gamma and electromagnetic induction logs collected at transect Km23, Assateague Island National Seashore, Maryland [Electromagnetic induction (EMI) conductivity was collected in millisiemens per meter ( $\mathrm{mS} / \mathrm{m})$; natural gamma in counts per second (cps); specific conductance in microsiemens per centimeter $(\mu \mathrm{S} / \mathrm{cm})$ at 25 degrees Celsius with the numeric value shown next to the blue scale bar; black and white striped box indicates the location of the screened interval]. 
$\mathrm{Km} 28 \mathrm{~B}$

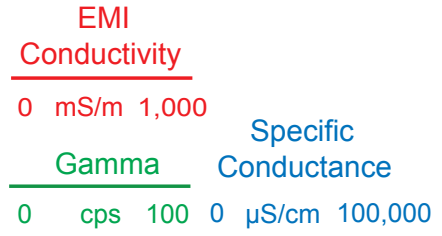

$-50$

Km28A

EMI

Conductivity

$0 \mathrm{mS} / \mathrm{m} \mathrm{1,000}$

Specific

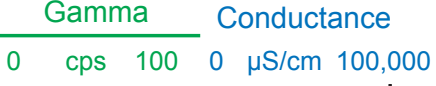

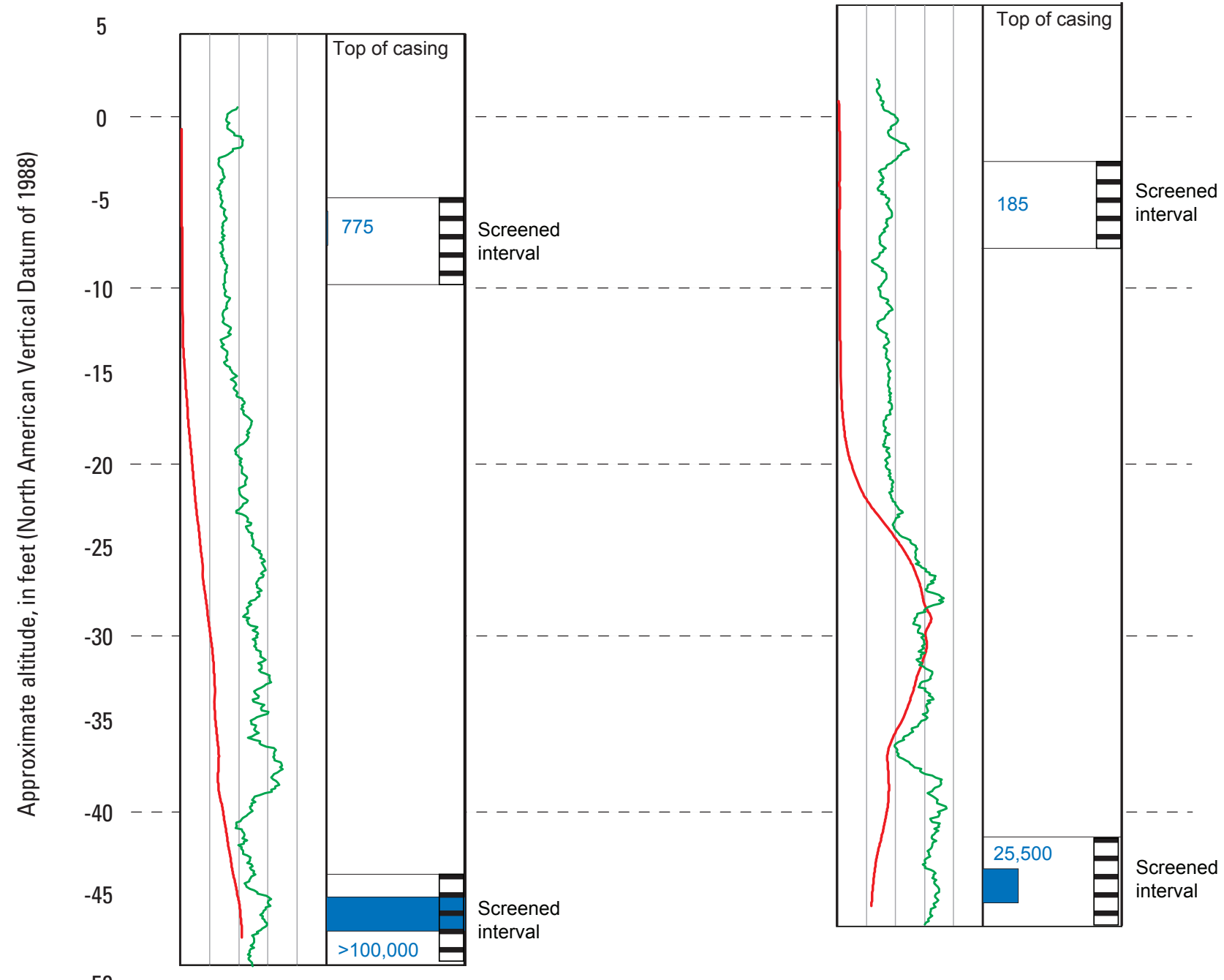

5

Figure 6e. Natural gamma and electromagnetic induction logs collected at transect Km28, Assateague Island National Seashore, Maryland [Electromagnetic induction (EMI) conductivity was collected in millisiemens per meter $(\mathrm{mS} / \mathrm{m})$; natural gamma in counts per second (cps); specific conductance in microsiemens per centimeter $(\mu \mathrm{S} / \mathrm{cm})$ at 25 degrees Celsius with the numeric value shown next to the blue scale bar; black and white striped box indicates the location of the screened interval]. 


\section{Summary}

The U.S. Geological Survey, through the Climate and Land Use Change Research and Development Program, conducted a multi-year investigation to assess potential impacts on the natural resources of Assateague Island National Seashore (ASIS), Maryland that may result from changes in the hydrologic system in response to projected sea-level rise. A network of 13 well pairs was installed to monitor shallow groundwater at ASIS. Well installation was completed between August 1 and August 13, 2010. Well location information, depths, and selected water-level data are provided, as well as latitude, longitude, and measuring-point altitude data for each well. Altitude data were acquired using a surveying tool linked to a global navigation satellite system and referenced to the North American Vertical Datum of 1988; uncertainty ranged from 0.05 to 0.13 feet. The altitude of all other wells in each transect was calculated relative to the well altitudes surveyed with the differential GPS technique.

Nine of the 26 wells were instrumented with water-level recording devices that collected continuous data at 15-minute intervals for a 7-week period in August and September 2010. Data from these wells were plotted along with tide data collected north of Assateague Island at the Ocean City Inlet tide gage and precipitation data collected by National Park Service staff at Assateague Island. These data indicate that precipitation events have the greatest effect on water levels in the shallow groundwater flow system whereas changes in the ambient sea level appear to have the greatest effect on water levels in the deeper wells. The water levels in both the shallow and deeper wells did not appear to be greatly influenced by the changing tides.

\section{Acknowledgments}

The authors would like to acknowledge Ms. Courtney Schupp, Mr. Jack Kumer, and Mr. Brian Sturgis of the National Park Service (NPS) for their scientific and logistical support. The authors would also like to acknowledge Dr. David Krantz of the University of Toledo for his work in advancing the understanding of the hydrogeomorphology at Assateague Island National Seashore. The authors extend thanks and appreciation to Mr. Brandon Fleming, Mr. Luke Myers, and Mr. Eric White of the USGS for their assistance in the collection of geophysical and hydrologic data.

\section{References Cited}

Dillow, J.J.A., Banks, W.S.L, and Smigaj, M.J., 2002, Groundwater quality and discharge to Chincoteague and Sinepuxent Bays adjacent to Assateague Island National Seashore, Maryland: U.S. Geological Survey WaterResources Investigations Report 02-4029, 42 p. (also available online at http://pubs.usgs.gov/wri/wri024029/ wri02-4029.pdf).

Keys, W.S., 1990, Borehole geophysics applied to groundwater investigations: U.S. Geological Survey Techniques of Water-Resources Investigations, book 2, chap. E-2, 149 p. (also available online at http://pubs.usgs.gov/twri/ twri2-e2/).

Krantz, D.E., 2009, A hydrogeomorphic map of Assateague Island National Seashore, Maryland and Virginia, accessed January 11, 2012 at http://www.eeescience.utoledo.edu/ Faculty/Krantz/download_files/NPS_Report.Assateague Hydrogeomorphology.pdf.

Masterson, J.P., and Garabedian, S.P., 2007, Effects of sea-level rise on ground water flow in a coastal aquifer system: Ground Water, v. 45, no. 2, p. 209-217, DOI: 10.1111/j.1745-6584.2006.00279.x.

National Oceanic and Atmospheric Administration, 2010, Center for Oceanographic Products and Services, tides and currents information, accessed December 5, 2010 at http:// tidesandcurrents.noaa.gov/index.shtml.

Owens, J.P., and Denny, C.S., 1979, Upper Cenozoic deposits of the central Delmarva Peninsula: U.S. Geological Survey Professional Paper, 1067-A, 28 p.

Pendleton, E.A., Williams, S.J., and Thieler, E.R., 2004, Coastal vulnerability assessment of Assateague Island National Seashore (ASIS) to sea-level rise: U.S. Geological Survey Open-File Report 2004-1020, 20 p. (also available online at http://pubs.usgs.gov/of/2004/1020/).

Schubert, C.E., 2010, Analysis of the shallow groundwater flow system at Fire Island National Seashore, Suffolk County, New York: U.S. Geological Survey Scientific Investigations Report 2009-5259, 106 p. (also available online at http://pubs.usgs.gov/sir/2009/5259/).

Taylor, K.C., Hess, J.W., and Massela, A. 1989, Field evaluation of a slim-hole induction tool: Ground Water Monitoring Review, v. 9, no. 1, p. 100-104, DOI: 10.1111/ j.1745-6592.1989.tb01125.x.

Williams, J.H., Lapham, W.W., and Barringer, T.H., 1993, Application of electromagnetic logging to contamination investigations in glacial sand-and-gravel aquifers: Ground Water Monitoring and Remediation, v. 13, no. 3, p. 129138, DOI: 10.1111/j.1745-6592.1993.tb00082.x. 
Prepared by USGS West Trenton Publishing Service Center. Edited by Valerie M. Gaine.

Graphics and layout by Timothy W. Auer.

For additional information, contact:

Director, MD-DE-DC Water Science Center

U.S. Geological Survey

5522 Research Park Drive

Baltimore, MD 21228

or visit our Web site at:

http://md.water.usgs.gov 
